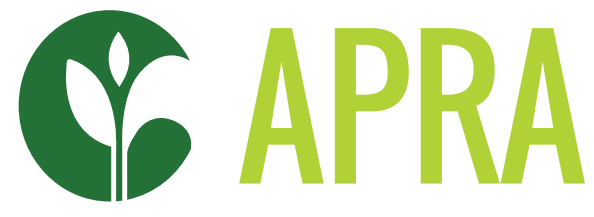

Agricultural Policy Research in Africa

\title{
RICE COMMERCIALISATION EFFECTS IN MNGETA, KILOMBERO DISTRICT, TANZANIA: IDENTIFYING THE UNDERLYING FACTORS
}

Aida Isinika, Gilead Mlay, Ntengua Mdoe, Gideon Boniface, Christopher Magomba and Devotha Kilave 


\section{CONTENTS}

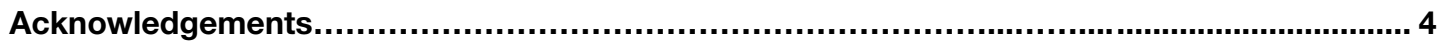

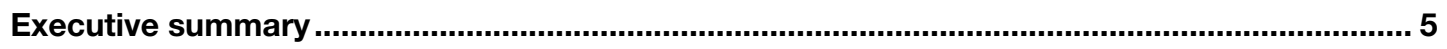

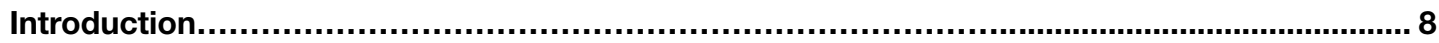

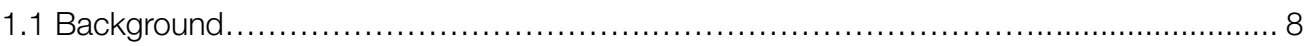

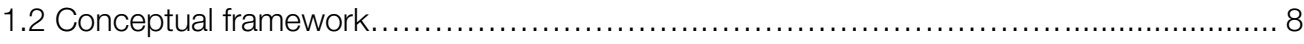

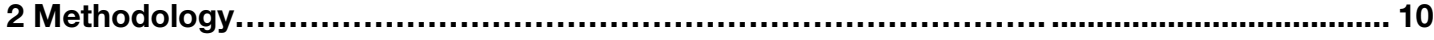

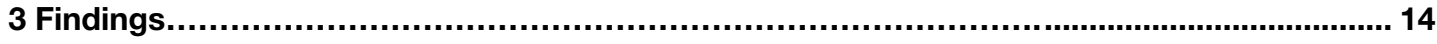

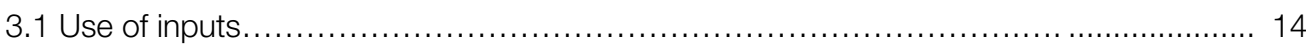

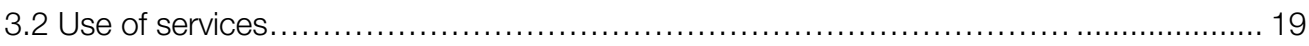

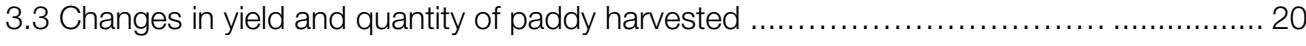

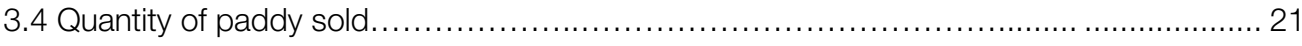

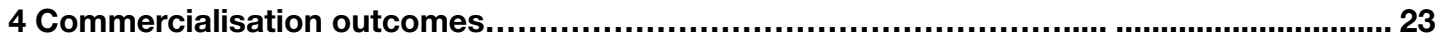

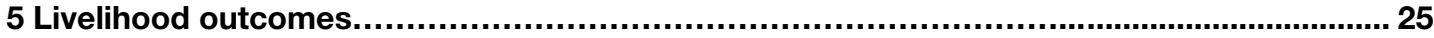

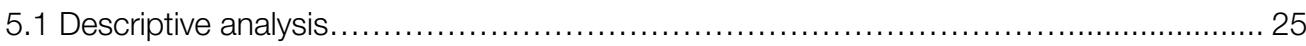

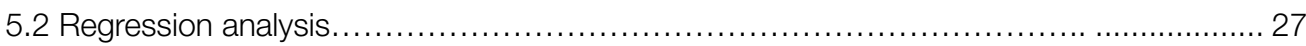

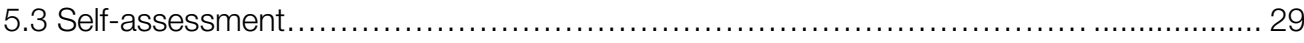

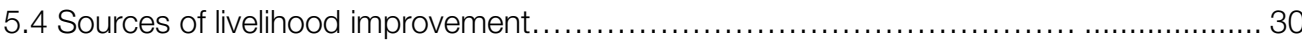

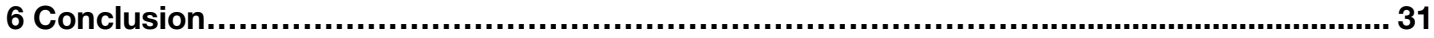

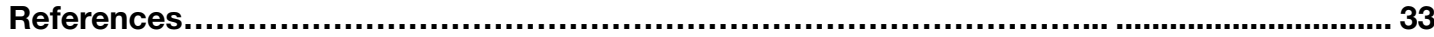

Annex 1 Sampling distribution for wave 1 and 2 by village and sex of household

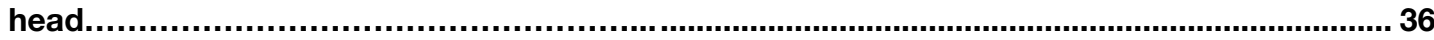

Annex 2 Sources of livelihood improvement by farmer category........................................ 37

Annex 3(a) Sources of livelihood improvement by commercialisation index...........................38

Annex 3(b) Sources of livelihood improvement by commercialisation index........................... 39

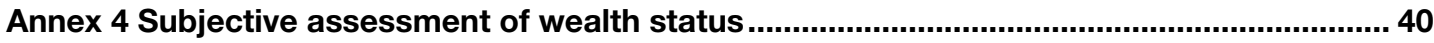

\section{List of tables and figures}

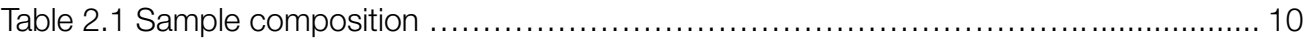

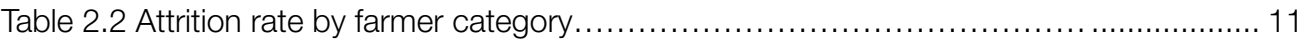

Table 2.3 Definition of explanatory/control variables.......................................... 12

Table 2.4 Variables used in estimating the welfare outcome equations.......................... 13

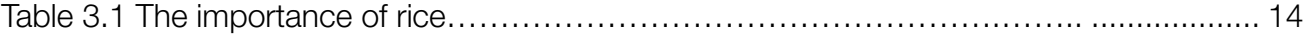

Table 3.2 Change in land ownership and land under rice...................................... 15 
Table 3.3 Changes in the proportion of households using inputs.

Table 3.4 Changes in the use of inputs by farmer category: purchased seed................ 16

Table 3.5 Changes in the use of inputs: inorganic and organic fertiliser.................... 17

Table 3.6 Changes in the use of inputs: services and hired labour....................... 18

Table 3.7 Percentage change in the use of inputs: tillage services.......................... 18

Table 3.8 Median levels of inputs used normalised per hectare ............................ 19

Table 3.9 Percentage of farmers using services: extension services and mobile money...... . 20

Table 4.1 Determinants of $\mathrm{RCl}$ in Kilombero District: pooled fractional probit..................... 24

Table 5.1 Determinants of welfare outcomes: pooled probit results......................... 28

Table 5.2 Sources of livelihood (MPI) improvement................................... 30

\section{Figures}

Figure 3.1 Changes in median yield $(\mathrm{kg} / \mathrm{ha})$ by farmer category $\ldots \ldots \ldots \ldots \ldots \ldots \ldots \ldots \ldots \ldots \ldots \ldots \ldots \ldots \ldots \ldots$

Figure 3.2 Median quantity of paddy harvested by farmer category....................... 21

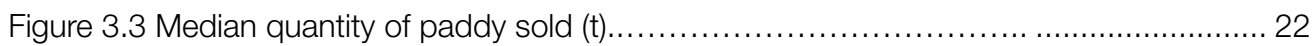

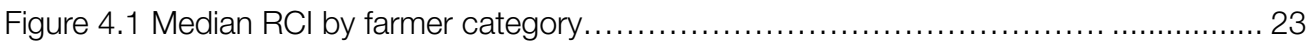

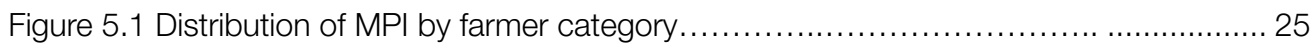

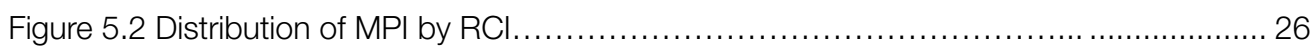

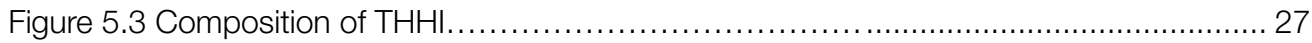




\section{ACKNOWLEDGEMENTS}

The research team is grateful for the generous funding from the UK's Department for International Development or Foreign, Commonwealth Development office (FCDO/DFDI) which supports the Agricultural Policy Research in Africa (APRA) consortium, under which this research was carried out. We are also very grateful for all the farmers and key informants in Mngeta division, Kilombero District who willingly agreed to share their experiences and stories about rice production and marketing, including their achievements as well as the challenges they continue to face. As these challenges are addressed, we envision a brighter future in rice and agricultural commercialisation in general with corresponding livelihood improvement not only in Kilombero District but other districts and regions around the country as well. The research team also appreciates the feedback given by APRA members, particularly, from the internal and external reviewers as well as the coordinating secretariat at the Institute of Development Studies (IDS) at the University of Sussex.

Aida Isinika is a professor at the Institute of Continuing Education. Gilead Mlay and Ntengua Mdoe are professors at the School of Agricultural Economics and Business Studies, Sokoine University of Agriculture, Tanzania. Gideon Boniface is an independent researcher based in Morogoro, Tanzania. Christoper Magomba is a lecturer at the School of Agricultural Economics and Business Studies while Devotha Kilave is a senior lecturer with the Institute of Continuing Education, Sokoine University of Agriculture.

This working paper is funded with UK aid from the UK government (Foreign, Commonwealth \& Development Office - FCDO, formerly DFID). The opinions are the authors and do not necessarily reflect the views or policies of IDS or the UK government. 


\section{LIST OF ABBREVIATIONS}

APRA

Agricultural Policy Research in Africa

FHH

female-headed household

$\mathrm{HCl}$

household commercialisation index

KPL

Kilombero Plantation Limited

LGA

Local Government Authority

MDD

minimum dietary diversity for women of reproductive age

MHH

male-headed household

MSF

medium-scale farmer

MPI

multi-poverty index

$\mathrm{RCI}$

rice commercialisation index

SRI

sustainable rice intensification

SSF

small-scale farmer

THHI

total household income

WS1

Work stream one

WS3

Work stream three 


\section{EXECUTIVE SUMMARY}

Rice production is the most dominant farming system in Kilombero valley in Morogoro region, Tanzania, accounting for more than 80 per cent of cultivated land within the valley. This paper examines changes in rice commercialisation and livelihood outcomes for different categories of farmers in the Mngeta division, Kilombero District, Tanzania. Understanding the trajectory of agricultural commercialisation processes is an important step because it has a direct bearing on livelihood outcomes: income from commercialisation finances livelihood improving expenditures within households. Understanding the underlying factors of agricultural commercialisation therefore enables policy makers to ensure that policy interventions promote inclusive and equitable involvement of all farmers and other value chain actors, especially women and youths, who have been excluded from most development initiatives in the past.

The paper is based on the premise that not everybody gains from agricultural commercialisation processes. Pathways of different farmer categories and other value chain actors differ due to variation in resource endowment and the choices they make in using available opportunity spaces. The paper uses data that was collected in two waves (2017 and 2019) from over 500 farmers in 10 villages within $30 \mathrm{~km}$ of Kilombero Plantation Limited (KPL), a large-scale rice farm within Mngeta Division in Kilombero District. The study's conceptual framework was set to test the assertion, promoted by the Southern Growth Corridor of Tanzania, that a large-scale investor, such as KPL would have positive technological spill over and market linkage effects to small-scale farmers (SSFs) and medium-scale farmers (MSFs) around them.

Farmers' commercialisation levels and corresponding livelihood outcomes were compared against the backdrop of village electrification as well as other public infrastructural investments (road, railway, communication infrastructure), which were found to have a positive influence on rice commercialisation. The rice commercialisation index $(\mathrm{RCl})$ in turn, together with some household characteristics such as sex of the household head, age, educational level, household size and the area of the land holding among others influenced variation in farmers' livelihood indicators including the multi-poverty index (MPI), food security and the minimum dietary diversity for women of child bearing age (MDD). During the first wave (2017), the analysis clearly showed that rice commercialisation was positively influenced by production intensification and area expansion (extensification). The same factors accounted for rice commercialisation variation among farmer categories during the second wave (2019). Although the interval between the two cross sections is too short to discern any trends in key variables, comparison between the two cross sections shows that rice commercialisation is not yet on a steady increasing trajectory. Across different farmer categories there is a general decline in the area under rice as well as in the use of some productivity increasing inputs, in particular purchased seed and organic fertiliser. There was also only a marginal increase in the use of some inputs and services (inorganic fertiliser, hired labour and tillage services and mobile money). However, there was a significant increase in the proportion of farmers using herbicides (+11.2 per cent) and a significant increase in the median volume of herbicides used per hectare (+22.4 per cent) as farmers substituted away from more expensive labour in rice production, especially for land clearing and weeding. There was also a significant increase (+5.6 per cent) in the proportion of farmers using tillage services, representing rice commercialisation by area expansion.

All these changes were not gender or age neutral. While the mean proportion of farmers using various inputs remained lower for female-headed households (FHHs) relative to male-headed households (MHHs), the improvement made between the two waves was higher for $\mathrm{FHHs}$ compared to $\mathrm{MHH}$, an indication of the former catching up with the latter. This is encouraging, pointing to the need to continue pursuing polices that promote inclusive agricultural commercialisation for FHHs to accommodate the specific need of women and young farmers who tend to face more resource constraints. The combined effect of changes in the use of inputs and services resulted in a marginal decline in yield, volume of paddy harvested and $\mathrm{RCl}$. The decline in $\mathrm{RCl}$ was particularly pronounced for sustainable rice intensification (SRI) members, which was attributed to termination of credit and advisory services from KPL since 2018, following closure of KPL's farming activities 
in the study area. The decline in $\mathrm{RCl}$ is also reflected in the regression analysis where the coefficient for year of data collection is negative and very highly significant.

Meanwhile, comparison of the MPI showed significant livelihood improvement across all farmer categories. The proportion of MPI poor households also declined significantly, especially among MHHs, MSFs and SRI members. Since there was a marginal decline in yield, paddy production and the volume of paddy sold, the improvement in livelihood indicators (MPI, food security and MDD) is explained by increased household income coming from the sale of other crops and non-income sources. Similar livelihood improvement was also observed in relation to food security and MDD. The decline in MPI has been associated with improvement in sanitation, improved quality of flooring in houses, reduced mortality among children under the age of five years and reduced deprivation in education for school age children.

All these findings can be summed up into two key points. First, rice commercialisation in the study area has not yet reached a steady increasing trajectory. The $\mathrm{RCl}$ is still susceptible to productivity and production changes due to weather variations including those induced by climate change. For instance, excessive rain and drought have both been experienced in the region. Additional changes include changes in input use and market factors. Second, it is important that farmers have a diversified portfolio, such that income from rice production is complemented by income from other crops as well as livestock and non-farm sources such that household food security is assured while embracing environmental sustainability. In such a pursuit, inclusive commercialisation must remain central so that $\mathrm{FHHs}$ and younger farmers are facilitated to catch up as everybody faces an upward mobility trend in livelihood improvement. Women account for approximately 43 per cent of the world's agricultural labour force. In Tanzania, women represent approximately 54 per cent of the agricultural labour force (Mmasa, n.d.), and a greater proportion of women than men (69.8 vs 64 per cent) work in agriculture (Idris, 2018). Moreover, studies have indicated that in agriculture women work up to 13 hours per week longer than men. Hence, if the world's women farmers had the same access to resources as men, 150 million people could be lifted out of poverty (FAO, 2021). Different interventions are necessary to sustain rice commercialisation among $\mathrm{FHHs}$ and younger farmers. These include ensuring access to capital through various ways such as government loan guarantees and the Local Government Authority (LGA) revenue allocated to the Women and Youth Development Fund as well as other funding sources and services targeting women and youth. 


\section{INTRODUCTION}

\subsection{Background}

Agricultural commercialisation is sought by governments and development partners because it has been associated with agricultural intensification and productivity improvements (Djurfeldt et al., 2019). This is expected to raise farmers' income from rising marketed surplus and lead to subsequent livelihood improvement. However, agricultural commercialisation is highly dynamic, affected by a wide range of biophysical, technological, socio-cultural, economic, institutional and policy related factors (Louw et al., 2008; Gupta, Vemireddy and Pingali, 2019; Pingali et al., 2019). These factors change over time and the changes may have positive or negative impacts on agricultural commercialisation and livelihoods. The negative impacts are more pronounced among women and other vulnerable resource poor people (Doss, 2001; Ajani, 2013).

This paper examines changes in rice commercialisation and the livelihoods of different categories of farmers in Kilombero valley in the Morogoro region, Tanzania since the 2016/17 farming season. Kilombero valley is the largest flood plain in East Africa covering about $6,300 \mathrm{~km}^{2}$. The climate is sub-humid tropical with a bimodal rainfall pattern divided in the short rains (November-January) and long rains (March-May) (Koutsouris et al., 2016). The flood-plain has many rivers and seasonal flooding, making it suitable for rain-fed rice production. The rice commercialisation process in the Kilombero valley is associated with the use of tractors introduced by large-scale farmers during the late 1980s and animal traction introduced by agropastoralists who have been immigrating into the valley since 2000. Specifically, the paper compares findings from the first and second wave of data collected under the Agricultural Policy Research in Africa (APRA) that was conducted in Tanzania as well as five other countries (Ethiopia, Ghana, Malawi, Nigeria and Zimbabwe). Research studies for APRA are conducted under the Future Agricultures Consortium (FAC), organised under three different work streams (WS1-WS3). In Tanzania, the first and second wave data were collected in 2017 and 2020 respectively for the crop season 2016/17 and 2018/19.

\subsection{Conceptual framework}

The study's conceptual framework recognises that not everybody gains from agricultural commercialisation processes. The pathway chosen by each household depends on the opportunity space available to them, which is a function of their resource endowment and their own ingenuity and dexterity to use such opportunities. Some farmers may simply "hang in" at the subsistence level if their options are limited due to resource constraints or some other shocks in the family (Doward, 2009). Others may "drop out" of agriculture when they fail to derive sustainable livelihoods due to constraints (especially access to land and labour) and external shocks, such as drought and floods. This may drive some of them into destitution, often as landless labourers (Verma and Verma, 1995). However, there are some farmers who succeed in agriculture and benefit through agricultural intensification or area expansion (extensification), thereby increasing their commercialisation levels or their share of sales. Under the APRA framework, such farmers are said to "step up", improving their livelihoods from agricultural enterprises. The other category of farmers also representing improvement are said to "step out" when they accumulate wealth from agricultural commercialisation for a while but eventually use the accumulated wealth to move into new areas of investment outside agriculture. These typologies of farmers reflect their level of inclusion or exclusion in commercialisation processes, which relates to access to and use of resources and corresponding productivity, commercialisation and livelihood outcomes. Where inclusion is high, the livelihoods of different farmer categories will improve in tandem. If exclusion is high, some categories of farmers will tend to stagnate or drop out (Dorward, 2009; Chirwa, Dorward and Matita, 2011). A typology of farmers, which was not specifically distinguished in this study, includes people who step into agriculture from non-agricultural backgrounds driven by a profit seeking motive. These include a recent wave of investors who are joining agriculture as MSFs whose main motivation is profit (Jayne et al., 2016). The original research design in Tanzania set out to assess the effect of a large-scale estate and public investment in infrastructure (railway, electricity and communication) 
on smallholder farmers' commercialisation response and corresponding livelihood, food security and equity outcomes.

Depending on a household's resource endowment and other confounding factors such as information, location relative to markets and other services as well as cultural factors, households differ in terms of technology adoption, division of labour and employment options along value chains. For example, farmers in urban villages with electricity have more non-farm options compared to farmers in remote villages without electricity. MSFs who own animal drawn technology are more likely to commercialise from area expansion. To examine the temporal effects of commercialisation, the APRA study under WS1 was designed as a panel study so that data would be collected at two points in time. This allows us to compare commercialisation across time in order to characterise farmers who step out, step up, hang in or step down and determine factors that lead to such outcome differences. The overarching question under the APRA conceptual framework is: which commercialisation pathways have the most effect on empowering women and girls, reducing rural poverty and improving nutrition and food security? In Tanzania this question is tested in a setting involving a large-scale investor surrounded by SSFs and MSFs. This present study aims to compare the commercialisation levels for different farmer categories and the corresponding impacts on income, livelihood, food security and dietary diversity among respondents. 
This paper presents the findings from two waves of data collected from ten villages in Mngeta division, Kilombero District Tanzania where rice is the most important economic activity for over 80 per cent of the population (Keto, 2007; Msuya and Isinika, 2017). The original research envisaged that commercialisation impacts would differ across villages depending on their distance from KPL - a large-scale rice investor who interacted with SSFS and MSFs in their vicinity by supporting a training programme with a credit component to promote SRI technologies. The KPL also provided some limited employment opportunities (Isinika et al., 2020).

Villages werealso expected to differ in commercialisation impacts according to their availability of electricity. This is because electrification attracts processors who invest in machinery and equipment that improve the quality of milling, enabling farmers to sell rice instead of paddy and hence get better returns (Isinika et al., 2020). Farmers were also classified according to farm size. The Ministry of Agriculture classifies farms according to land area where farms below 5ha are small, 5.1-20ha are medium and those above 20ha are large, which is consistent with ongoing studies on the emergence of MSFs (Jayne et al., 2020; Wineman et al., 2020). In the original sample of 2017, 16 out of 537 respondents had farms between 21 and 200ha, putting them in the large-scale category. However, relative to KPL, which has 5,800ha, even the farms exceeding 20ha were, for the purpose of this study, classified as medium-scale.

A two-stage sampling design was used to select farmers. In the first stage, ten villages were selected from three strata. Four of the ten villages came from the first stratum where electricity was present during the first wave of data collection in October 2017. Another four villages came from the second stratum, where electricity connectivity was expected by 2018 , one year before the second wave of data collection in 2019. These were referred to as switch villages. The last two villages were selected from the third stratum, where there would be no electricity by 2019 - at the time of the second wave of data collection. Therefore, the four villages selected for the first stratum were Chita, Itongoa, Mngeta and Mchombe. The switch villages in the second stratum were Makutano, Nakaguru, Mkusi and Njage. Ijia and Luvilikila were selected for the third stratum. Stratified random sampling was then used in the second stage to select SSFs and MSFs within villages. In each village, the number of SRI members was small and they fell under both categories (SSF and MSF). Hence all SRI members in each study village were included in the sample.

During the first wave of data collection, 559 households were selected from a population comprising of 7,156 households in the study area (Isinika et al., 2018), but only 537 were used for analysis due to missing data. During the second wave, the sample was increased to

Table 2.1 Sample composition

\begin{tabular}{|l|l|l|l|l|l|l|l|}
\hline \multirow{2}{*}{ Household characteristic } & \multicolumn{2}{|c|}{2017} & \multicolumn{3}{c|}{ Households } & \multicolumn{2}{c|}{2019} \\
\cline { 3 - 9 } & Number & $\%$ & Panel & New & Total & $\%$ \\
\hline \multirow{3}{*}{ Electricity } & With electricity & 223 & 41.5 & 303 & 364 & 667 & 82.7 \\
\cline { 2 - 9 } & Without electricity & 314 & 58.5 & 66 & 74 & 140 & 17.3 \\
\hline \multirow{3}{*}{ Sex of household head } & Female & 66 & 12.3 & 59 & 70 & 129 & 16 \\
\cline { 2 - 9 } & Male & 471 & 87.7 & 310 & 368 & 678 & 84 \\
\hline Farmer category & SSF & 357 & 66.5 & 232 & 390 & 622 & 77.1 \\
\cline { 2 - 9 } & MSF & 74 & 13.8 & 46 & 48 & 94 & 11.6 \\
\cline { 2 - 9 } & SRI & 106 & 19.7 & 91 & 0 & 91 & 11.3 \\
\hline & Whole sample & $\mathbf{5 3 7}$ & $\mathbf{1 0 0}$ & $\mathbf{3 6 9}$ & $\mathbf{4 3 8}$ & $\mathbf{8 0 7}$ & $\mathbf{1 0 0}$ \\
\cline { 2 - 8 } & \% & $\mathbf{1 0 0}$ & - & $\mathbf{4 5 . 7}$ & $\mathbf{5 4 . 3}$ & $\mathbf{-}$ & $\mathbf{1 0 0}$ \\
\hline
\end{tabular}

Source: Authors' own 
807 households comprising of 438 new (53.4 per cent) and 369 old (47.7 per cent) households, but only 801 were used for analysis due to incomplete information for the remaining six. The sample composition by village is given in Annex 1 while the summary of sample composition by farmer category is presented in Table 2.1.

For the panel sample there was a high attrition of 168 households equivalent to 31.3 per cent (Table 2.2), which is attributed to difficulties in reaching some of the respondents during the second wave since data was collected during the rainy season. In addition, there is high mobility of farmers before the onset of the farming season as farmers migrate to new villages in search of alternative rental land. Not all changes within farmer categories are however attributed to attrition. For example, households in villages with electricity increased by 66.6 per cent (from 223-667) because four villages in the switching stratum had electricity by 2019 instead of 2018 which resulted in a corresponding decline of households without electricity by 44.6 per cent (from 314-140). Thus, the changes reported for the other categories reflect the combined effect of switching villages, attrition and the additional new sample in 2019.

Agricultural commercialisation is a process driven by market demand and it may be accelerated by public and private investment as well as facilitation by development agencies (Poulton, 2017, Wiggins et al., 2014). This implies that the trend of agricultural commercialisation may slow down or even reverse if some of these investments and facilitation decline. It is expected that inclusive agricultural commercialisation processes will close the gap, measured by indicators of productivity, production, share of sale, livelihood, food and nutrition security. This study uses data collected under two waves (2017 and 2019) to compare these indicators between the two cross sections, for different categories of famers. While comparison is also made for the panel data, it should be noted that the interval of two years (2017-2019) is too short to make meaningful temporal implications.
Effective agricultural commercialisation is also expected to improve the livelihood outcome of participating households in terms of improved food security, nutrition, quality of house, education for children - to mention a few examples. Therefore, the analysis determines whether there was upward mobility or otherwise of livelihood and food security indicators; and whether such mobility is linked to rice commercialisation. Based on the data we can only assess farmers who step-up and those who hangin. Farmers who step up use gains accumulated from previous rice production or trading to make further productivity improvement and corresponding livelihood improvement. Farmers who hang-in will experience stagnation in key indicators of input use, productivity, livelihood, food and nutrition security between the two waves. The descriptive analysis compares commercialisation levels across farmers categories. Meanwhile, regression analysis is used to discern the determinants of rice commercialisation.

The Tobit regression model, used during the first wave, is replaced by a pooled cross section fractional probit model to accommodate an unbalanced sample of 537 respondents for the first wave and 801 for the second wave. The fractional probit model is presented in equation (1).

$$
E\left(Y_{t} \mid X_{t}\right)=\Theta\left(X_{t} \beta\right) 0 \leq Y \leq 1, t=1,2
$$

Where:

$\mathrm{Y}=$ fraction of rice harvested that is sold by a household sampled in year $t$

$\mathrm{X}=$ explanatory and control variables influencing the proportion of rice sold by a household. The variables and expected signs are summarised in Table 2.3.

$\pm \theta(\mathrm{Xt} \beta)=$ is the normal cumulative distribution function $\beta=$ A vector of parameters to be estimated

Table 2.2 Attrition rate by farmer category

\begin{tabular}{|l|l|l|l|l|}
\hline \multirow{2}{*}{ Characteristic } & \multicolumn{2}{|c|}{ Panel 2017 } & Panel 2019 & \multicolumn{2}{|c|}{ Attrition } \\
\cline { 4 - 6 } & & & N & $\%$ \\
\hline With electricity & 233 & 303 & +80 & +35.9 \\
\hline Without electricity & 314 & 66 & -248 & -79.0 \\
\hline Female & 66 & 59 & -7 & -10.6 \\
\hline Male & 471 & 310 & -161 & -34.2 \\
\hline SSF & 357 & 232 & -125 & -35.0 \\
\hline MSF & 74 & 46 & -28 & -37.8 \\
\hline SRI & 106 & 91 & -15 & -14.2 \\
\hline Whole sample & 537 & 369 & 169 & -31.3 \\
\hline
\end{tabular}

Source: Authors' own 
While rice commercialisation contributes to household cash income, it is not a good indicator of livelihood and wellbeing (Ogut and Quam, 2018; Kirui and Njirau, 2013). The cost of translating income into wellbeing varies across households depending on individual attributes and availability of services within localities (Sen, 1999). Poverty was therefore measured using the MPI, which accommodates several factors of poverty including assets, health, education and nutrition attributes of a household (Alkire, 2016). Descriptive analysis is used to compare poverty levels between farmer categories while logit regression analysis is used to assess factors accounting for temporal changes in livelihood and food security indicators across the two waves. The model for estimating determinants of MPI changes is given in Equation 2.

$$
Y_{t}^{*}=X_{t} \theta+\varepsilon_{t}
$$

Where:

$\mathrm{Y}_{\mathrm{t}}^{*}=\mathrm{a}$ continuous latent variable reflecting the level of household wellbeing in year $\mathrm{t}$

$\mathrm{X}_{\mathrm{t}}=$ explanatory/control variables influencing $\mathrm{y} *$ in year $\mathrm{t}$

$\epsilon_{\mathrm{t}}=$ idiosyncratic error terms assumed to be independent, identical and normally distributed

$\theta=$ parameters to be estimated
The determinants of welfare outcomes (poverty, food security and dietary diversity) were analysed using a pooled probit model as indicated by Equation 3 which is obtained from the index model presented in Equation 2. The main focus is on the influence of rice commercialisation on household welfare outcomes after controlling for other factors.

Let $\mathrm{Y}$ be the observable wellbeing status of $\mathrm{a}$ household. It is a dummy variable assigned a value of 1 or 0 as follows;

(i) $\mathrm{Y}=1$ if a household is multidimensionally poor (i.e. the MPI score is > 0.33) and 0 otherwise

(ii) $\mathrm{Y}=1$ if a household is food secure and 0 otherwise

(iii) $\mathrm{Y}=1$ if household meets MDD and 0 otherwise. Where:

$$
P_{\left(Y_{t}=1\right)}=\theta\left(X_{t} \beta\right)
$$

$\theta\left(X_{t} \beta\right)=$ is the normal cumulative distribution function leading to a probit model

The variables used in the probit model are presented in Table 2.4.

\begin{tabular}{|c|c|c|}
\hline Variable & Description & $\begin{array}{l}\text { Expected } \\
\text { sign }\end{array}$ \\
\hline Year & A dummy variable, assigned 1 if second wave of the survey and 0 if first wave. & $-/+$ \\
\hline Age & Age of household head, a proxy for experience or willingness to take risk. & $-/+$ \\
\hline Sex & Sex of household head, assigned 1 if female and 0 if male. & - \\
\hline Household size & Reflects households' total food needs. & - \\
\hline Total land & Reflects the potential for agricultural production and production for the market. & + \\
\hline Distance to a rice mill & Access to processing and storage. & - \\
\hline Use of purchased seed & A dummy variable, assigned a 1 if used, 0 if otherwise. & + \\
\hline Use of inorganic fertilisers & A dummy variable assigned a 1 if used, 0 if otherwise. & + \\
\hline Use of organic fertilisers & A dummy variable assigned a 1 if used, 0 if otherwise. & + \\
\hline Use of herbicides & A dummy variable assigned a 1 if used, 0 if otherwise. & + \\
\hline Use of tillage services & A dummy variable assigned a 1 if used, 0 if otherwise. & + \\
\hline Type of farmer 1 (MSF) & $\begin{array}{l}\text { A dummy variable assigned a value of } 1 \text { if MSF and } 0 \text { otherwise. Expected to } \\
\text { commercialise more than SSFs. }\end{array}$ & + \\
\hline Type of farmer 2 (SRI) & $\begin{array}{l}\text { A dummy variable, assigned a value of } 1 \text { if SRI member and } 0 \text { otherwise. } \\
\text { Expected to commercialise more that SSFs by being more productive. }\end{array}$ & + \\
\hline
\end{tabular}

Table 2.3 Definition of explanatory/control variables for rice commercialisation

Source: Authors' own 
Table 2.4: Variables used in estimating the welfare outcome equations

\begin{tabular}{|c|c|c|c|c|}
\hline \multirow[t]{2}{*}{ Variable } & \multirow[t]{2}{*}{ Description } & \multicolumn{3}{|c|}{$\begin{array}{l}\text { Expected signs by welfare } \\
\text { outcome }\end{array}$} \\
\hline & & MPI & FS & MDD \\
\hline Year of survey & Dummy variable assigned a 1 if second wave, 0 if otherwise. & $-/+$ & $-/+$ & $-/+$ \\
\hline Age & Age of household head. & $-/+$ & $-/+$ & $-/+$ \\
\hline Education & Years of schooling. & - & + & + \\
\hline Sex & $\begin{array}{l}\text { Sex of household head - a dummy variable assigned a } 1 \text { if } \\
\text { female, } 0 \text { if otherwise. }\end{array}$ & + & - & - \\
\hline Household size & Number of people in a household. & + & - & - \\
\hline Electricity & $\begin{array}{l}\text { Dummy variable assigned a } 1 \text { if the village has electricity, } 0 \text { if } \\
\text { otherwise. Electricity opens opportunities for additional sources } \\
\text { of income and provision of social services. }\end{array}$ & - & + & + \\
\hline Rice area & Expansion of rice output under ceteris paribus conditions. & - & + & + \\
\hline Rice yield & Increased output per unit of land. & - & + & + \\
\hline Farmer type 1 & Dummy variable assigned a 1 if MSF and 0 if otherwise. & - & $-/+$ & + \\
\hline Farmer type 2 & Dummy variable assigned a 1 if SRI farmer and 0 if otherwise. & - & - & + \\
\hline Type of farmer 2 (SRI) & A dummy variable, assigned a value 0 & + & + & + \\
\hline
\end{tabular}

Source: Authors' own 
By definition agricultural commercialisation involves increasing the use of purchased inputs. The first point of assessing agricultural commercialisation change is therefore at the level of inputs use. For rice production this must be assessed in relation to changes in the cropping and enterprise mix. The analysis shows that rice remains the most important crop both in terms of the proportion of households growing crops, the percentage of plots under the crop and the area planted with rice for the top five crops (Tables 3.1 and 3.2). For most of the comparison analysis involving quantitative indicators we use median values because the corresponding mean values tend to be skewed to the right.

Study findings revealed that there was a general decline in the median land holdings for most farmer categories. The decrease is mostly attributed to the new sampled households whose median was 1.62ha compared to 1.82ha for the panel sample during the second wave. However, some farmer categories such as in villages without electricity experienced $a+41$ per cent increase in the median land holdings, while $\mathrm{MHH}$ and SRI members experienced about 40 per cent and 20 per cent increase in the median area under rice respectively (Table 3.2). Likewise, there was a general decline in the median area under rice from 1.42ha to 1.21 ha for the whole sample, being the largest among MHHs (-41 per cent) and SSFs (-30 per cent). Correspondingly, the mean area under rice declined by 19.3 per cent from 2.7ha in 2017 to 2.2ha in 2019.

Not all the land used for rice production is owned. About 20 per cent of the farmers in the sample rented land for rice production. The proportion of renters declined slightly to 19.7 per cent in 2019 compared to 23.5 per cent in 2017. During both periods a slightly higher proportion of $\mathrm{FHHs}$ rented land compared to the MHHs. However, the proportion of households that rented out land did not change significantly. A significantly higher proportion of SSFs (26.5 per cent) rented in land compared to 21.7 per cent among SRI members and 12.2 per cent for MSFs. In 2019 a higher proportion of SRI members (24.2 per cent) rented in land compared to 19.8 per cent among SSFs and 14.8 per cent among MSFs. Incidences of renting out land are higher among FHHs relative to MHHs; MSFs compared to SSFs and SRI members; and in villages with electricity relative to villages without electricity.

\subsection{Use of inputs}

Agricultural commercialisation is associated with higher use of productivity increasing inputs which leads to crop intensification as well as production increasing inputs such as tillage implements, which lead to area expansion. In the context of this study the inputs included purchased seed, inorganic fertiliser, farmyard manure, agrochemicals (pesticides and herbicides), tools and implements as well as hired labour. Comparison was made for the proportion of households using these inputs as proxies to gauge rice commercialisation changes between the two waves as presented in Table 3.3.

According to these findings there was a positive change showing a higher proportion of farmers using all inputs except purchased seed and farmyard manure. The

Table 3.1 The importance of rice

\begin{tabular}{|c|c|c|c|c|c|c|}
\hline \multirow[t]{2}{*}{ Crop } & \multicolumn{2}{|c|}{ Per cent of households } & \multirow[t]{2}{*}{ Change } & \multicolumn{2}{|c|}{ Per cent of plots } & \multirow[t]{2}{*}{ Change } \\
\hline & 2017 & 2019 & & 2017 & 2019 & \\
\hline Paddy/rice & 97.3 & 98.2 & +0.9 & 74.6 & 75.1 & +0.5 \\
\hline Maize & 42.2 & 33.9 & -8.3 & 18.8 & 17 & -1.8 \\
\hline Cassava & 2.7 & 0.3 & -2.4 & 0.1 & 0.3 & +0.2 \\
\hline Peas & 2.2 & 1.4 & -0.8 & 0.6 & 0.7 & +0.1 \\
\hline Sweet potatoes & 1.2 & 0.6 & -0.6 & 0.1 & 0.3 & +0.2 \\
\hline Groundnuts & 4 & 2.8 & -1.2 & 1.3 & 1.3 & 0 \\
\hline
\end{tabular}

Source: Authors' own 
positive trend is consistent with increasing agricultural intensification, while increasing use of tillage services and hired labour corresponds to extensification. Both trends have been associated with rising commercialisation (Isinika et al., 2020). The largest increase occurred in the use of herbicides where 11.2 per cent more households used the input in 2019 relative to 2017 when comparing the whole sample, and 12 per cent for the panel sample. Meanwhile, the decline of households using purchased seed and farmyard manure was associated with their limited availability. It should be noted however that purchased seed in this sample may not represent improved seed since farmers merely buy seed from each other since improved rice seed is not readily available in input shops in most parts of Tanzania.

If these changes are inclusive, it is expected that all the farmer categories will also increase their use proportional to changes reported in Table 3.3. The

Table 3.2 Change in land ownership and land under rice

\begin{tabular}{|c|c|c|c|c|c|c|c|}
\hline \multirow{2}{*}{\multicolumn{2}{|c|}{ Farmer category }} & \multicolumn{3}{|c|}{ Median land owned (ha) } & \multicolumn{3}{|c|}{ Median land under rice (ha) } \\
\hline & & 2017 & 2019 & $\begin{array}{l}\text { Per cent } \\
\text { change }\end{array}$ & 2017 & 2019 & $\begin{array}{l}\text { Per cent } \\
\text { change }\end{array}$ \\
\hline \multicolumn{8}{|c|}{ Whole sample } \\
\hline \multirow[t]{2}{*}{ Electricity status } & With electricity & 2.02 & 1.62 & -40 & 1.22 & 1.21 & -1 \\
\hline & Without electricity & 2.02 & 2.43 & +41 & 1.62 & 1.62 & 0 \\
\hline \multirow[t]{2}{*}{ Sex of household head } & Female & 1.51 & 1.21 & -31 & 0.81 & 0.81 & 0 \\
\hline & Male & 2.07 & 1.82 & -25 & 1.62 & 1.21 & -41 \\
\hline \multirow[t]{3}{*}{ Farmer category } & SSF & 1.62 & 1.32 & -30 & 1.62 & 1.32 & -30 \\
\hline & MSF & 8.90 & 8.10 & -80 & 8.90 & 8.1 & -40 \\
\hline & SRI & 2.43 & 2.43 & 0 & 1.62 & 1.82 & +20 \\
\hline Sample mean & & 2.02 & 1.62 & -40 & 1.42 & 1.21 & -21 \\
\hline Significance of difference & & & & 0.015 & & & 0.017 \\
\hline \multicolumn{8}{|c|}{ Panel sample } \\
\hline \multirow[t]{2}{*}{ Electricity status } & With electricity & 2.02 & 1.62 & -40 & 1.22 & 1.22 & -1 \\
\hline & Without electricity & 2.02 & 2.42 & +41 & 1.62 & 1.82 & +20 \\
\hline \multirow[t]{2}{*}{ Sex of household head } & Female & 1.52 & 1.21 & -31 & 0.81 & 0.81 & 0 \\
\hline & Male & 2.07 & 1.82 & -25 & 1.62 & 1.62 & 0 \\
\hline \multirow[t]{3}{*}{ Farmer category } & SSF & 1.62 & 1.32 & -30 & 1.62 & 0.91 & -71 \\
\hline & MSF & 8.90 & 8.1 & -80 & 7.70 & 6.78 & -92 \\
\hline & SRI & 2.43 & 2.43 & 0 & 1.62 & 1.82 & +20 \\
\hline Sample mean & & 2.02 & 1.82 & +20 & 1.42 & 1.21 & -21 \\
\hline Significance of difference & & & & 0.015 & & & 0.017 \\
\hline
\end{tabular}

Source: Authors' own

Table 3.3 Changes in the proportion of households using inputs

\begin{tabular}{|l|l|l|l|l|l|l|}
\hline \multirow{2}{*}{ Input } & \multicolumn{3}{|c|}{ Whole sample (\%) } & \multicolumn{3}{c|}{ Panel sample (\%) } \\
\cline { 2 - 8 } & 2017 & 2019 & Change & 2017 & 2019 & Change \\
\hline Purchased seed & 21.8 & 13.5 & -8.3 & 21.8 & 13.9 & -7.9 \\
\hline Inorganic fertiliser & 14.7 & 17.1 & +2.4 & 14.7 & 15.6 & +0.9 \\
\hline Organic fertiliser & 2.4 & 0.3 & -2.1 & 2.4 & 0.3 & -2.1 \\
\hline Herbicides & 61.1 & 72.3 & +11.2 & 61.1 & 73.1 & +12 \\
\hline Hired labour & 73.1 & 75.4 & +2.3 & 73.1 & 75.4 & +2.3 \\
\hline Tillage services & 89.5 & 95.1 & +5.6 & 89.5 & 95.7 & +6 \\
\hline
\end{tabular}

Source: Authors' own 
analysis which follows (Tables 3.4-3.8) tests this assumption by assessing the magnitude of changes in input use for different categories of farmers. There was an 8.3 per cent decline in the proportion of households using purchased seed for the whole sample and 7.9 per cent decline for panel households. However, the median use of seed $(\mathrm{kg} / \mathrm{ha})$ between the two cross sections increased from 54.7 to 61.7 per cent representing a 12.8 per cent increase. Contrary to expectations, the highest decline occurred among SRI members who were leading on productivity performance during the first wave (2017), which was attributed to higher technology adoption (Isinika et al., 2020). The observed decline may reflect their reduced tendency to practice SRI technologies, which include using better quality seed.

The high proportion of farmers reporting a decline in the use of purchased seed is probably associated with the termination of input and credit facilitation which for SRI members was coordinated by KPL extension personnel until 2017. During the 2019/2020 crop season, the KPL farm was no longer operating. Decline was also high in villages with electricity. The level of decline was higher for $\mathrm{MHH}$ s relative to $\mathrm{FHHs}$. For the other inputs, while there was a general increasing trend, some categories of farmers experienced a decline. For example, for both the whole and panel sample, MSFs and SRI members experienced a decline in the use of inorganic fertiliser. All categories of farmers experienced a decline or stagnation in the use of organic fertiliser and SRI members experienced a decline in the use of herbicides.

The proportion of farmers using inorganic or artificial fertiliser increased by 2.4 per cent for the whole sample and by 0.9 per cent for the panel sample (Table 3.5).
The highest increase occurred among $\mathrm{FHHs}$, although some farmer categories experienced a decline. Notable among these is the 4.2 per cent decline in the proportion of SRI members using inorganic fertiliser. As stated earlier, this is probably due to the termination of credit and advisory services previously provided by KPL during the 2017/18 farming season.

This was corroborated by our observation during the second wave data collection in February 2020, where it was noted that inorganic fertiliser was in short supply in the study area. Input suppliers reported that if they sold at the government directed retail price they would not break even. Therefore, most of them did not stock fertiliser rather than sell above the approved price and risk being apprehended. The proportion of increased households was lower for the panel sample compared to the whole sample for 2019, which implies the additional households had lower mean fertiliser use than the resampled panel households. This is consistent with the newly sampled household heads being significantly older. Analysis during the first wave showed that the age of the household head had a negative effect on commercialisation (Isinika et al., 2020), meanwhile other studies have established that younger farmers perform better than older farmers in terms of productivity and profit efficiency (Msuya et al., 2018). The proportion of farmers using farmyard manure or organic fertiliser was very low in 2017 (2.4 per cent), which was attributed to limited availability and technical difficulty in applying the manure on large farms due to lack of appropriate tools. The proportion of farmers using this input declined to only 0.3 per cent in 2019, being most notable among SRI members, who as explained earlier had the highest productivity performance in 2017 because they applied inputs effectively including organic fertiliser.

Table 3.4 Changes in the use of inputs by farmer category: purchased seed

\begin{tabular}{|l|l|l|l|l|l|l|l|}
\hline \multirow{2}{*}{ Farmer category } & \multicolumn{3}{|c|}{ Whole sample (\%) } & \multicolumn{3}{c|}{ Panel sample (\%) } \\
\cline { 3 - 8 } & 2017 & 2019 & Change & 2017 & 2019 & Change \\
\hline \multirow{2}{*}{ Electricity status } & With electricity & 24.3 & 13.5 & -10.8 & 25.3 & 13.9 & -10.4 \\
\cline { 2 - 8 } & Without electricity & 20.1 & 13.2 & -6.9 & 20.1 & 13.8 & -6.3 \\
\hline \multirow{3}{*}{ Sex of household head } & Female & 16.4 & 11.5 & -4.9 & 16.4 & 14.3 & -2.1 \\
\cline { 2 - 8 } & Male & 22.6 & 13.8 & -8.8 & 22.6 & 13.8 & -8.8 \\
\hline Farmer category & SSF & 24.0 & 15.4 & -8.6 & 24.0 & 18.0 & -6 \\
\cline { 2 - 8 } & MSF & 9.7 & 6.5 & -3.2 & 9.7 & 6.5 & -3.2 \\
\cline { 2 - 8 } & SRI & 23.3 & 7.8 & -15.5 & 23.3 & 7.8 & -15.5 \\
\hline Sample mean & $\mathbf{2 1 . 8}$ & $\mathbf{1 3 . 5}$ & $\mathbf{- 8 . 3}$ & $\mathbf{2 1 . 8}$ & $\mathbf{1 3 . 9}$ & $\mathbf{- 7 . 9}$ \\
\hline Significance of change (p value) & & & $\mathbf{0 . 0 0 4}$ & & & $\mathbf{0 . 0 0 4}$ \\
\hline
\end{tabular}

Source: Authors' own 
Meanwhile the proportion of farmers applying herbicides and pesticides recorded a highly significant increase (Table 3.6) and much of the increase is attributed to herbicide use. Focus group discussions with farmers and key informants revealed that the increasing trend in using herbicides for weed control was their attempt to substitute away from more expensive labour. High levels of increase are also observed among SSFs and FHHs (13.6 per cent) compared to MHHs. This may be interpreted as a sign of stepping up and inclusion for these categories of farmers. As noted earlier in relation to $\mathrm{SRI}$ members, this category experienced a 6.8 per cent decline in the proportion of farmers using pesticides/herbicides, which as stated earlier is linked to the KPL's business termination.

The use of hired labour also increased by 2.3 per cent in 2019 relative to 2017 (Table 3.6), but the direction of change varies across farmer categories. The highest increase occurred among MSFs probably to cope with increased labour requirements due to area expansion. There was also a significant increase among $\mathrm{FHH}$ reflecting a tendency of labour and skills shortage in these households (Doss and Moris, 2001; Ombakah, 2014).
Area expansion has been another avenue of increasing total farm production, which feeds into rising commercialisation. The findings in Table 3.7 show a highly significant increase $(p=0.002)$ in the use of tillage services (oxen, tractor and power tillers), which facilitated area expansion. The highest increase occurred among FHHs at 16.2 per cent for the whole sample and 16 per cent for panel households. These households often face labour and income constraints. With these households stepping up in acquiring inputs, including hiring tillage services is a positive indication towards inclusion. However, it is noted that the level of increase was very small for MSFs and there was even a decrease for MSFs in the panel sample (Table 3.7). This may reflect the tendency of MSFs to own oxen, hence being less dependent on hired services for tillage and related farm operations.

Thus far the data reflect a mixed direction of change in the proportion of households using key productivity and production increasing inputs (some increased while others declined). In order to gauge whether agricultural intensification or extensification was happening proportionally across different farmer

Table 3.5 Changes in the use of inputs: inorganic fertiliser and farmyard manure

\begin{tabular}{|c|c|c|c|c|c|c|c|}
\hline \multirow{2}{*}{\multicolumn{2}{|c|}{ Farmer category }} & \multicolumn{3}{|c|}{ Whole sample } & \multicolumn{3}{|c|}{ Panel sample } \\
\hline & & 2017 & 2019 & Change & 2017 & 2019 & Change \\
\hline \multicolumn{8}{|l|}{ (a) Inorganic fertiliser } \\
\hline \multirow[t]{2}{*}{ Electricity status } & With electricity & 17.1 & 18.4 & +1.3 & 17.1 & 16.3 & -0.8 \\
\hline & Without electricity & 12.9 & 11.0 & -1.9 & 12.9 & 12.3 & -0.6 \\
\hline \multirow[t]{2}{*}{ Sex of household head } & Female & 8.2 & 18.6 & +10.4 & 8.2 & 16.3 & +8.1 \\
\hline & Male & 15.6 & 16.8 & +1.2 & 15.6 & 15.5 & -0.1 \\
\hline \multirow[t]{3}{*}{ Farmer category } & SSF & 10.0 & 16.4 & +1.6 & 10.0 & 12.9 & +2.9 \\
\hline & MSF & 11.1 & 10.9 & -0.2 & 11.1 & 4.3 & -6.8 \\
\hline & SRI & 32.0 & 27.8 & -4.2 & 32.0 & 27.8 & -4.2 \\
\hline \multicolumn{2}{|l|}{ Sample mean } & 14.7 & 17.1 & +2.4 & 14.7 & 15.6 & +0.9 \\
\hline \multicolumn{2}{|c|}{ Significance of change ( $p$ value) } & & & 0.008 & & & 0.008 \\
\hline \multicolumn{8}{|l|}{ (b) Organic fertiliser } \\
\hline \multirow[t]{2}{*}{ Electricity status } & With electricity & 3.8 & 0.3 & -3.5 & 3.8 & 0.3 & -3.5 \\
\hline & Without electricity & 1.4 & 0.0 & -1.4 & 1.4 & 0.0 & -1.4 \\
\hline \multirow[t]{2}{*}{ Sex of household head } & Female & 1.6 & 0.0 & -1.6 & 1.6 & 0.0 & -1.6 \\
\hline & Male & 2.5 & 0.3 & -2.2 & 2.5 & 0.3 & -2.2 \\
\hline \multirow[t]{3}{*}{ Farmer category } & SSF & 0.6 & 0.3 & -0.3 & 0.6 & 0.5 & -0.1 \\
\hline & MSF & 0.0 & 0.0 & 0.0 & 0.0 & 0.0 & 0 \\
\hline & SRI & 9.7 & 0.0 & -9.7 & 9.7 & 0.0 & -9.7 \\
\hline \multicolumn{2}{|l|}{ Sample mean } & 2.4 & 0.3 & -2.1 & 2.4 & 0.3 & -2.1 \\
\hline \multicolumn{2}{|c|}{ Significance of change ( $p$ value) } & & & 0.00 & & & 0.00 \\
\hline
\end{tabular}

Source: Authors' own 
categories such that inclusion can be assessed across time and farmer categories, we compare the median levels of input used, normalised per hectare. The analysis shows that the distribution of most input use is skewed to the right such that most mean values are higher than corresponding median values. For this reason, we used median values to present all normalised indicators of input use including land holdings and area under rice as already presented (Table 3.2)

Table 3.6 Changes in the use of inputs: pesticides/herbicides and hired labour

\begin{tabular}{|c|c|c|c|c|c|c|c|}
\hline \multirow{2}{*}{\multicolumn{2}{|c|}{ Farmer category }} & \multicolumn{3}{|c|}{ Whole sample } & \multicolumn{3}{|c|}{ Panel sample } \\
\hline & & 2017 & 2019 & Change & 2017 & 2019 & Change \\
\hline \multicolumn{8}{|l|}{ Herbicides } \\
\hline \multirow[t]{2}{*}{ Electricity status } & With electricity & 64.8 & 71.9 & +7 & 64.1 & 72.9 & +8.1 \\
\hline & Without electricity & 58.5 & 74.3 & +15.8 & 58.5 & 73.8 & +15.3 \\
\hline \multirow[t]{2}{*}{ Sex of household head } & Female & 59.0 & 72.6 & +13.6 & 59.0 & 81.6 & +22.6 \\
\hline & Male & 61.4 & 72.3 & +10.9 & 61.4 & 71.7 & +10.3 \\
\hline \multirow[t]{3}{*}{ Farmer category } & SSF & 54.4 & 72.3 & +17.9 & 54.4 & 73.7 & +19.3 \\
\hline & MSF & 70.8 & 76.1 & +5.3 & 70.8 & 78.3 & +7.5 \\
\hline & SRI & 75.7 & 68.9 & -6.8 & 75.7 & 68.9 & -6.8 \\
\hline \multicolumn{2}{|l|}{ Sample mean } & 61.1 & 72.3 & +11.2 & 61.1 & 73.1 & +12 \\
\hline \multicolumn{2}{|c|}{ Significance of change ( $p$ value) } & & & 0.016 & & & 0.016 \\
\hline \multicolumn{8}{|l|}{ Hired labour } \\
\hline \multirow[t]{2}{*}{ Electricity status } & With electricity & 81.9 & 77.1 & -4.5 & 81.9 & 77.4 & -4.5 \\
\hline & Without electricity & 66.9 & 67.6 & +0.7 & 66.9 & 66.2 & -0.7 \\
\hline \multirow[t]{2}{*}{ Sex of household head } & Female & 71.0 & 78.8 & +7.8 & 71.0 & 85.7 & +14.7 \\
\hline & Male & 73.4 & 74.8 & +1.4 & 73.4 & 73.7 & +0.3 \\
\hline \multirow[t]{3}{*}{ Farmer category } & SSF & 68.8 & 71.7 & +2.9 & 68.8 & 70 & +4.9 \\
\hline & MSF & 79.5 & 88.0 & +8.5 & 79.5 & 78.3 & -1.2 \\
\hline & SRI & 82.5 & 86.7 & +4.2 & 82.5 & 86.7 & +4.2 \\
\hline \multicolumn{2}{|l|}{ Sample mean } & 73.1 & 75.4 & +2.3 & 73.1 & 75.4 & +2.3 \\
\hline \multicolumn{2}{|c|}{ Significance of change ( $p$ value) } & & & 0.00 & & & 0.00 \\
\hline
\end{tabular}

Source: Authors' own

Table 3.7 Percentage change in the use of inputs: tillage services

\begin{tabular}{|c|c|c|c|c|c|c|c|}
\hline \multicolumn{2}{|l|}{ Farmer category } & \multicolumn{3}{|c|}{ Whole sample (\%) } & \multicolumn{3}{|c|}{ Panel sample (\%) } \\
\hline & & 2017 & 2019 & Change & 2017 & 2019 & Change \\
\hline \multirow[t]{2}{*}{ Electricity status } & With electricity & 91.4 & 95.4 & +4 & 91.4 & 95.1 & +3.7 \\
\hline & Without electricity & 88.1 & 93.4 & +5.3 & 88.1 & 90.8 & +2.7 \\
\hline \multirow[t]{2}{*}{ Sex of household head } & Female & 82.0 & 98.2 & +16.2 & 82.0 & 98.0 & +16 \\
\hline & Male & .90 .5 & 94.4 & +4 & 90.5 & 93.8 & +3.3 \\
\hline \multirow[t]{3}{*}{ Farmer category } & SSF & 87.2 & 944 & +7.2 & 87.2 & 92.6 & +11.4 \\
\hline & MSF & 94.4 & 94.6 & +0.2 & 94.4 & 91.3 & -3.1 \\
\hline & $\mathrm{SRI}$ & 93.2 & 100 & +6.8 & 93.2 & 100 & +6.8 \\
\hline \multicolumn{2}{|l|}{ Sample mean } & 89.5 & 95.1 & +5.6 & 89.5 & 94.3 & +4.8 \\
\hline \multicolumn{2}{|c|}{ Significance of change ( $p$ value) } & & & 0.002 & & & 0.002 \\
\hline
\end{tabular}

Source: Authors' own 
The findings show that despite a marginal increase in the median level of using inorganic fertiliser (from $52.9 \mathrm{~kg} / \mathrm{ha}$ in 2017 to $55.7 \mathrm{~kg} / \mathrm{ha}$ in 2019 , representing a $5.3 \mathrm{~kg} / \mathrm{ha}$ increase). most farmer categories experienced a decline ranging from $-6.7 \mathrm{~kg} / \mathrm{ha}$ among $\mathrm{SRI}$ members to $-37.9 \mathrm{~kg} / \mathrm{ha}$ among $\mathrm{FHHs}$. Only $\mathrm{MHH}$ s experienced an increase $(+23.7 \mathrm{~kg} / \mathrm{ha})$ while SSFs stagnated, experiencing no change. Using the panel sample the findings show that the median use of inorganic fertiliser declined from 52.9kg/ha in 2017 to $51.2 \mathrm{~kg} / \mathrm{ha}$, equivalent to a $3.2 \mathrm{~kg} / \mathrm{ha}$ decline (Table 3.8). Even though these sample mean changes were not statistically significant for the whole sample as well as for the panel sample, there were variations across categories. The decline was higher for farmers in villages without electricity $(-22.3 \mathrm{~kg} / \mathrm{ha})$ compared to those in villages with electricity which experienced a marginal increase $(+0.3 \mathrm{~kg} / \mathrm{ha})$. For the panel sample there was a general decline ranging from -36.4 per cent among MSFs to -6.7 per cent among SRI members. The high rate of decline among $\mathrm{FHH}$ members could reflect their exclusion while the decline observed among SRI members has been associated with cessation of credit and advisory support following the closure of KPL farming activities since 2018.

\subsection{Use of services}

In addition to inputs, other services including extension services are generally known to have positive impacts on improving productivity. The analysis in Table 3.9 shows that there was a highly significant increase in the proportion of farmers using extension services across all categories of farmers except for farmers who owned over 20ha where the use of these services decreased by 26.6 per cent. The proportion of increase was significantly higher for farmers in villages with electricity; not significantly different by gender; and higher for SSFs compared to MSFs and SRI members, which is an indication of SSFs catching up and hence reflecting inclusion since extension services deliberately target SSFs.

The use of mobile money is quite high among farmers, about 76.7 and 83.4 per cent of the respondents

Table 3.8 Median levels of inputs used normalised per hectare

\begin{tabular}{|c|c|c|c|c|c|c|c|}
\hline \multirow{2}{*}{\multicolumn{2}{|c|}{ Farmer category }} & \multicolumn{3}{|c|}{ Whole sample } & \multicolumn{3}{|c|}{ Panel sample } \\
\hline & & 2017 & 2019 & $\%$ Change & 2017 & 2019 & $\%$ Change \\
\hline \multicolumn{8}{|c|}{ (a) Inorganic fertiliser (kg/ha) } \\
\hline \multirow[t]{2}{*}{ Electricity status } & With electricity & 58.3 & 58.5 & +0.3 & 58.3 & 52.9 & -9.3 \\
\hline & Without electricity & 49.4 & 38.4 & -22.3 & 49.4 & 49.4 & 0 \\
\hline \multirow[t]{2}{*}{ Sex of household head } & Female & 70.5 & 43.8 & -37.9 & 70.5 & 60.9 & -13.6 \\
\hline & Male & 49.4 & 61.1 & +23.7 & 49.4 & 61.8 & +25.1 \\
\hline \multirow[t]{3}{*}{ Farmer category } & SSF & 61.7 & 61.7 & 0 & 61.7 & 61.8 & +0.2 \\
\hline & MSF & 32.1 & 28.5 & -11.2 & 32.1 & 20.4 & -36.4 \\
\hline & SRI & 54.9 & 51.2 & -6.7 & 54.9 & 51.2 & -6.7 \\
\hline \multicolumn{2}{|l|}{ Sample mean } & 52.9 & 55.7 & +5.3 & 52.9 & 51.2 & -3.2 \\
\hline \multicolumn{2}{|l|}{ F value } & \multicolumn{2}{|c|}{0.045} & & \multicolumn{2}{|c|}{0.095} & \\
\hline \multicolumn{2}{|l|}{ Significance level } & \multicolumn{2}{|c|}{0.832} & & \multicolumn{2}{|c|}{0.909} & \\
\hline \multicolumn{8}{|l|}{ (b) Herbicides } \\
\hline \multirow[t]{2}{*}{ Electricity status } & With electricity & 3.19 & 3.74 & +17.2 & 3.19 & 3.33 & +4.4 \\
\hline & Without electricity & 2.46 & 3.29 & +33.7 & 2.46 & 2.96 & +20.3 \\
\hline \multirow[t]{2}{*}{ Sex of household head } & Female & 2.45 & 3.62 & +47.8 & 2.45 & 3.29 & +34.3 \\
\hline & Male & 2.45 & 3.71 & +51.4 & 2.45 & 3.29 & +34.3 \\
\hline \multirow[t]{3}{*}{ Farmer category } & SSF & 2.45 & 3.95 & +61.2 & 2.45 & 3.71 & +51.4 \\
\hline & MSF & 2.45 & 3.29 & +34.3 & 2.45 & 3.22 & +31.4 \\
\hline & SRI & 3.17 & 3.29 & +3.8 & 3.17 & 3.29 & +3.8 \\
\hline \multicolumn{2}{|l|}{ Sample mean } & 2.47 & 3.71 & +50.2 & 2.47 & 3.29 & +33.2 \\
\hline \multicolumn{2}{|l|}{ F value } & \multicolumn{2}{|c|}{$24.8^{\star \star \star}$} & & \multicolumn{2}{|c|}{$13.2^{\star \star \star}$} & \\
\hline \multicolumn{2}{|l|}{ Significance level } & \multicolumn{2}{|c|}{0.00} & & \multicolumn{2}{|c|}{0.00} & \\
\hline
\end{tabular}

Source: Authors' own 
reported to have used the services in 2017 and 2019 respectively (Table 3.9). This variable has been used as an indicator for positive changes towards financial inclusion for rural dwellers who face limited access to traditional financial institutions ((https://www.fsdt.or.tz/ finscope/ 2017). The highest participation rate in 2019 as well as the highest proportion of increase occurred among MSFs who experienced a 20.5 per cent increase. However, $\mathrm{FHH}$ faced stagnation as there was no change for the whole sample and a decline for the panel sample, the only category of farmers to record a decline in using mobile money. This implies their inclusion into rice commercialisation is limited when access to such services does not increase at the same pace as the rest of the sample and implicitly the population. The effect of farmers using different levels of inputs and services for rice production is reflected in their productivity performance, which in this study is represented by yield $(\mathrm{kg} / \mathrm{ha})$, a partial productivity indicator.

\subsection{Changes in yield and quantity of paddy harvested}

The ultimate outcome of using inputs and services is to improve productivity. The findings in Figures 3.1 show that for the sample as a whole, there was a marginal increase in median yield (7.7 per cent) between 2017 and 2019 both for the whole and the panel sample but the difference was not significant ( $p$ value $=0.705$ and 0.242 respectively). The changes were not in the same direction across all categories of famers. The yields in villages with electricity remained higher than those without electricity. In the case of gender, $\mathrm{FHHs}$ experienced a higher decline for the whole sample (-19.3 per cent) compared to the panel sample $(-6.3$

Table 3.9 Percentage of farmers using services: extension services and mobile money

\begin{tabular}{|c|c|c|c|c|c|c|c|c|c|}
\hline \multirow{2}{*}{\multicolumn{2}{|c|}{ Farmer category }} & \multicolumn{3}{|c|}{ Whole sample (\%) } & \multicolumn{3}{|c|}{ Panel sample (\%) } & \multicolumn{2}{|c|}{$\begin{array}{c}\text { Proportional } \\
\text { change }\end{array}$} \\
\hline & & 2017 & 2019 & Change & 2017 & 2019 & Change & Sample & Pane \\
\hline \multicolumn{10}{|c|}{ Extension services } \\
\hline \multirow[t]{2}{*}{$\begin{array}{l}\text { Electricity } \\
\text { status }\end{array}$} & $\begin{array}{l}\text { With } \\
\text { electricity }\end{array}$ & 54.1 & 68.2 & 14.1 & 54.1 & 69.3 & 15.2 & 26.1 & 28.1 \\
\hline & $\begin{array}{l}\text { Without } \\
\text { electricity }\end{array}$ & 39.4 & 55.7 & 16.3 & 36.7 & 57.6 & 20.9 & 41.4 & 56.9 \\
\hline \multirow{2}{*}{$\begin{array}{l}\text { Sex of } \\
\text { household } \\
\text { head }\end{array}$} & Female & 39.4 & 59 & 19.6 & 37.4 & 66.7 & 29.3 & 49.7 & 78.3 \\
\hline & Male & 44.8 & 67.3 & 22.5 & 44.8 & 67.3 & 22.5 & 50.2 & 50.2 \\
\hline \multirow{3}{*}{$\begin{array}{l}\text { Farmer } \\
\text { category }\end{array}$} & SSF & 38.7 & 65.3 & 26.6 & 38.7 & 65.5 & 26.8 & 68.7 & 69.3 \\
\hline & MSF & 40.5 & 59.6 & 19.1 & 40.5 & 54.3 & 13.8 & 47.2 & 34.1 \\
\hline & SRI & 65.1 & 78 & 12.9 & 65.1 & 78 & 12.9 & 19.8 & 19.8 \\
\hline \multicolumn{2}{|c|}{ Sample mean } & 44.3 & 68.3 & 24 & 44.3 & 67.2 & 22.9 & 54.2 & 51.7 \\
\hline \multicolumn{2}{|l|}{ Chi square } & \multicolumn{2}{|c|}{0.00} & & \multicolumn{2}{|c|}{0.00} & & & \\
\hline \multicolumn{10}{|c|}{ Mobile money } \\
\hline \multirow[t]{2}{*}{$\begin{array}{l}\text { Electricity } \\
\text { status }\end{array}$} & $\begin{array}{l}\text { With } \\
\text { electricity }\end{array}$ & 83.3 & 84.2 & 0.9 & 83.3 & 83 & -0.3 & 1.1 & -0.4 \\
\hline & $\begin{array}{l}\text { Without } \\
\text { electricity }\end{array}$ & 71.7 & 78.1 & 6.4 & 71.7 & 78.8 & 7.1 & 8.9 & 9.9 \\
\hline \multirow{2}{*}{$\begin{array}{l}\text { Sex of } \\
\text { household } \\
\text { head }\end{array}$} & Female & 66.7 & 66.7 & 0 & 66.7 & 56.6 & -10.1 & 0.0 & -15.1 \\
\hline & Male & 78 & 86 & 8 & 78 & 86.6 & 8.6 & 10.3 & 11.0 \\
\hline \multirow{3}{*}{$\begin{array}{l}\text { Farmer } \\
\text { category }\end{array}$} & SSF & 74.1 & 80.4 & 6.3 & 74.1 & 75.3 & 1.2 & 8.5 & 1.6 \\
\hline & MSF & 76.7 & 92.4 & 15.7 & 76.7 & 97.8 & 21.1 & 20.5 & 27.5 \\
\hline & SRI & 84.9 & 92 & 7.1 & 84.9 & 92 & 7.1 & 8.4 & 8.4 \\
\hline \multicolumn{2}{|c|}{ Sample mean } & 76.7 & 83.4 & 6.7 & 76.7 & 82.6 & 5.9 & 8.7 & 7.7 \\
\hline \multicolumn{2}{|l|}{ Chi square } & \multicolumn{2}{|c|}{0} & & \multicolumn{2}{|c|}{0} & & & \\
\hline
\end{tabular}

Source: Authors' own 
per cent), implying that the newly sampled household had lower yields on average. Meanwhile, $\mathrm{MHH}$ experienced a higher decline in the panel sample (-22.4 per cent) compared to the whole sample $(-8.4$ per cent).

The SSFs experienced a lower level of decline compared to SRI members. Meanwhile, the MSFs experienced yield improvement almost twice as much for the panel sample (+27.8 per cent) compared to the whole sample (+13.3 per cent). The higher level of decline among SRI members has been attributed to a decline in credit and advisory services, previously provided by KPL. However, despite the absence of advisory services from KPL, SRI members reported a 19.8 per cent increase in the proportion of farmers using extension services provided by the LGA. The combined effect of yield and total area under production determines the amount of paddy that is harvested by each household as reported in Figure 3.2.

\section{Figure 3.1: Changes in median yield (kg/ha) by farmer category}

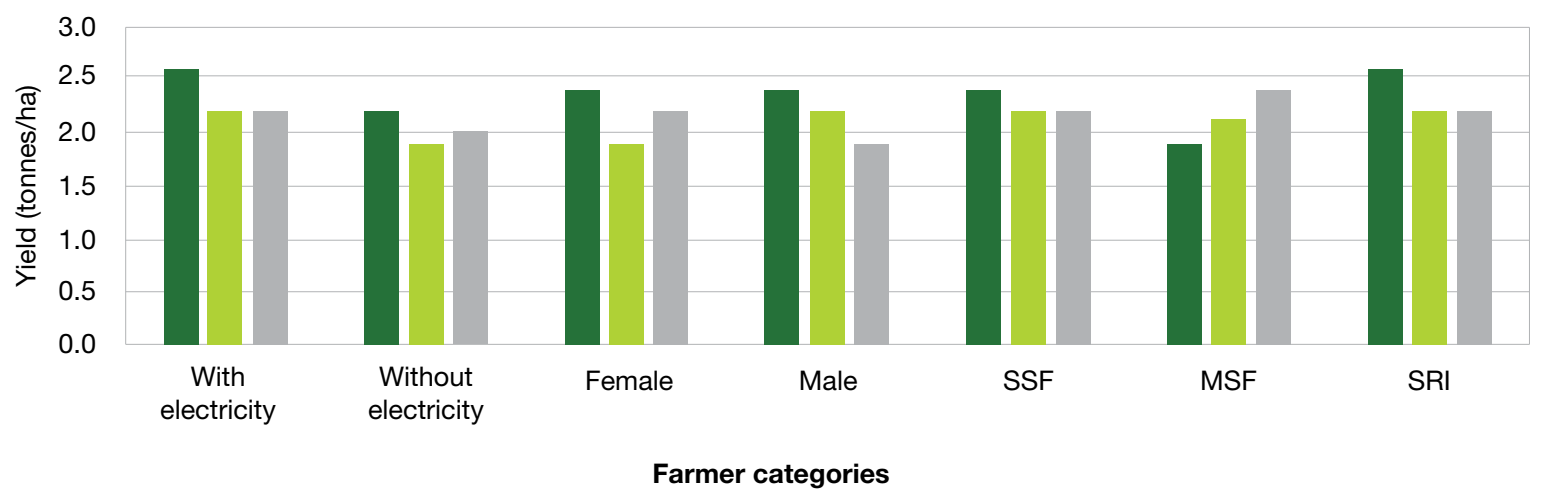

Sample 2017 Sample 2019 Panel 2019

Source: Authors' own

Figure 3.2: Median quantity of paddy harvested by farmer category

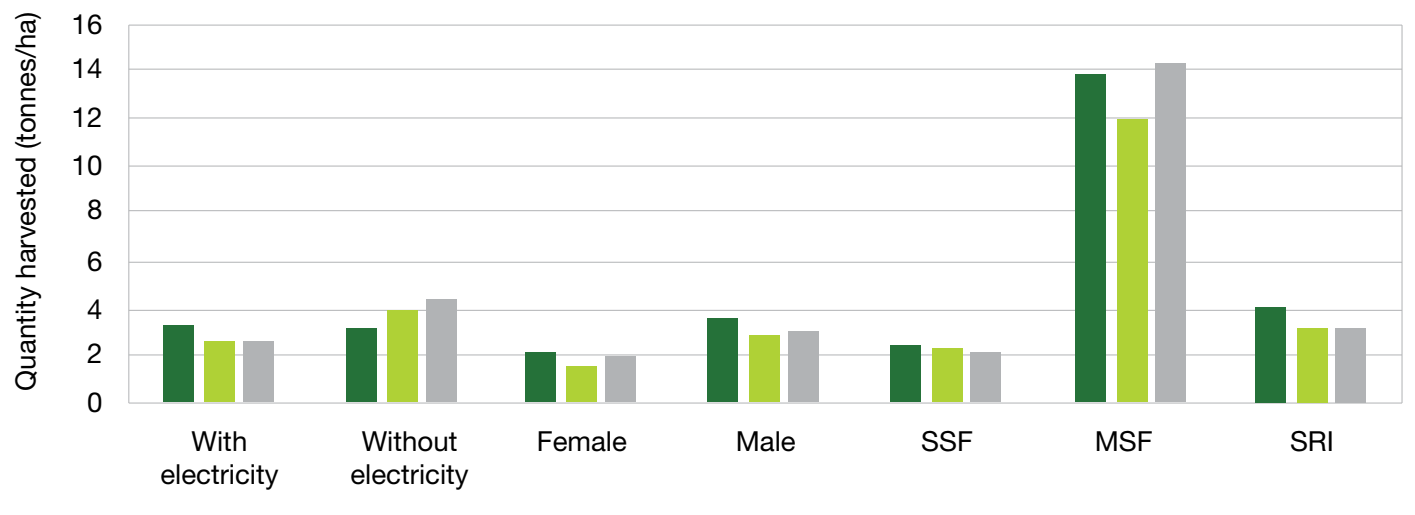

Farmer categories

Whole sample 2017

Whole sample 2019

Panel sample 2019

Source: Authors' own 
Figure 3.3 Median quantity of paddy sold (t)

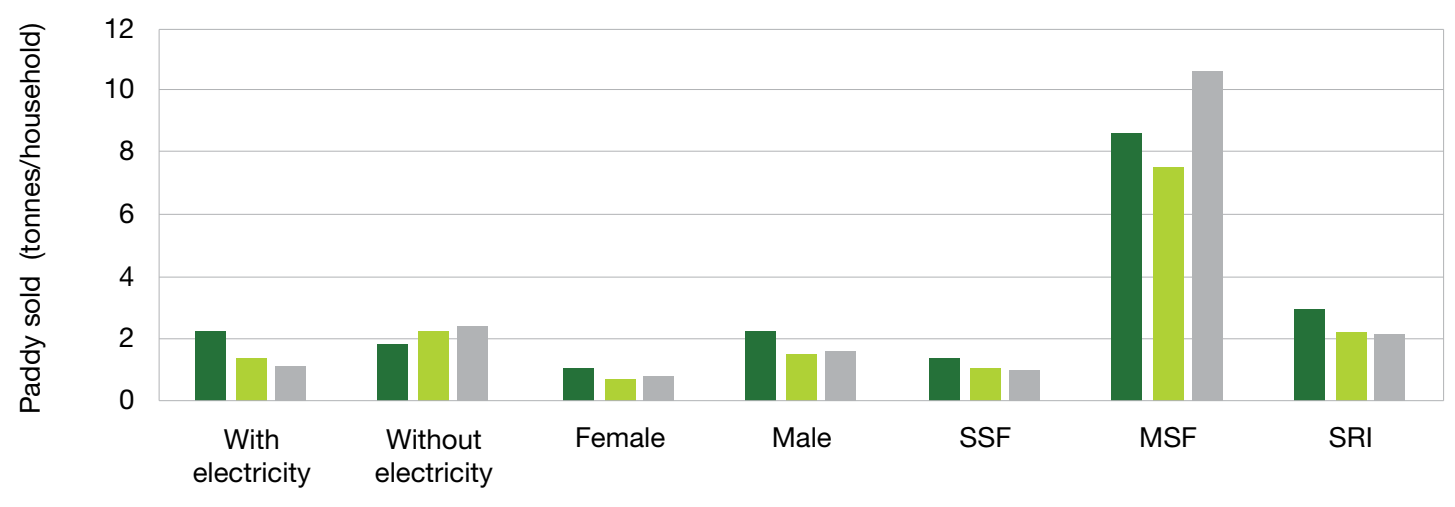

Farmer categories

\begin{tabular}{l|l|l|l|} 
Whole sample 2017 & Whole sample 2019 & Panel sample 2019
\end{tabular}

Source: Authors' own 


\section{COMMERCIALISATION OUTCOMES}

Having examined the trend in the use of inputs and the outcomes in terms of yield and the quantity of paddy harvested and that is sold per household, we used the normalised indicator to measure the share of paddy that was sold relative to the quantity harvested. Normally the household commercialisation index $(\mathrm{HCl})$, an aggregate share of all crops sold, is used. However, in this study, the area under rice accounted for over 90 per cent of the cropped land, covering about 75 per cent of all the plots and land under crops (Table 3.1). On this basis therefore, a case was previously made to use the $\mathrm{RCl}$ instead of the $\mathrm{HCl}$ (Isinika et al., 2020). The $\mathrm{RCl}$ is a ratio of the value of the paddy or rice harvested by a farmer to the value of total paddy or rice harvested from all the plots they planted and harvested in a given season.

The findings show that both the mean and median rice commercialisation declined across all farmers categories (Figure 4.1), the highest rate being recorded among SRI where the median $\mathrm{RCl}$ declined by 8.4 per cent compared to 5.1 and 4.4 per cent for MSFs and SSFs respectively. Comparison by gender shows that MHHs experienced ahigher level of decline of the median $\mathrm{RCl}$ but the difference was not significant. The general decline in $\mathrm{RCl}$ indicates that rice commercialisation in the study area is not yet on a steady rising path, being susceptible to fluctuations due to weather and market forces. Hence, more needs to be done to ensure that commercialisation improvement is cumulative and sustainable. Regression analysis is used to determine factors that influence variation in $\mathrm{RCl}$. The $\mathrm{RCl}$ was regressed against a number of variables as defined in equation (1) and Table 2.3. The findings are presented in Table 4.1.

The model has a log likelihood ratio of -754.82 whose Wald Chi square value is 179.26 with 16 degrees of freedom that is very highly significant $(p=0.00)$, which reflects the model's goodness of fit. Out of 15 variables, only three were not significant. Variables which had positive and very highly significant influence on commercialisation included, with corresponding marginal effects indicated in parentheses: access to extension services (0.054), use of organic fertiliser (0.2), tillage services (0.127) and use of herbicides (0.048). Another set of variables with positive and significant influence on $\mathrm{RCl}$ variation included the use of inorganic fertiliser (0.049) and non-farm income (0.0006). Other studies have similarly established the important role of non-farm income on poverty reduction (Katega, 2014; Ombakah, 2014). The influence of these two variables on commercialisation was much higher in 2019 compared to 2017, which may reflect the importance of an effective agricultural extension system to increase the adoption rate of new technologies. The $\mathrm{RCl}$ of farmers who had received extension services was likely to be higher by 0.054 per cent compared to non-recipients.

\section{Figure 4.1 Median RCl by farmer category}

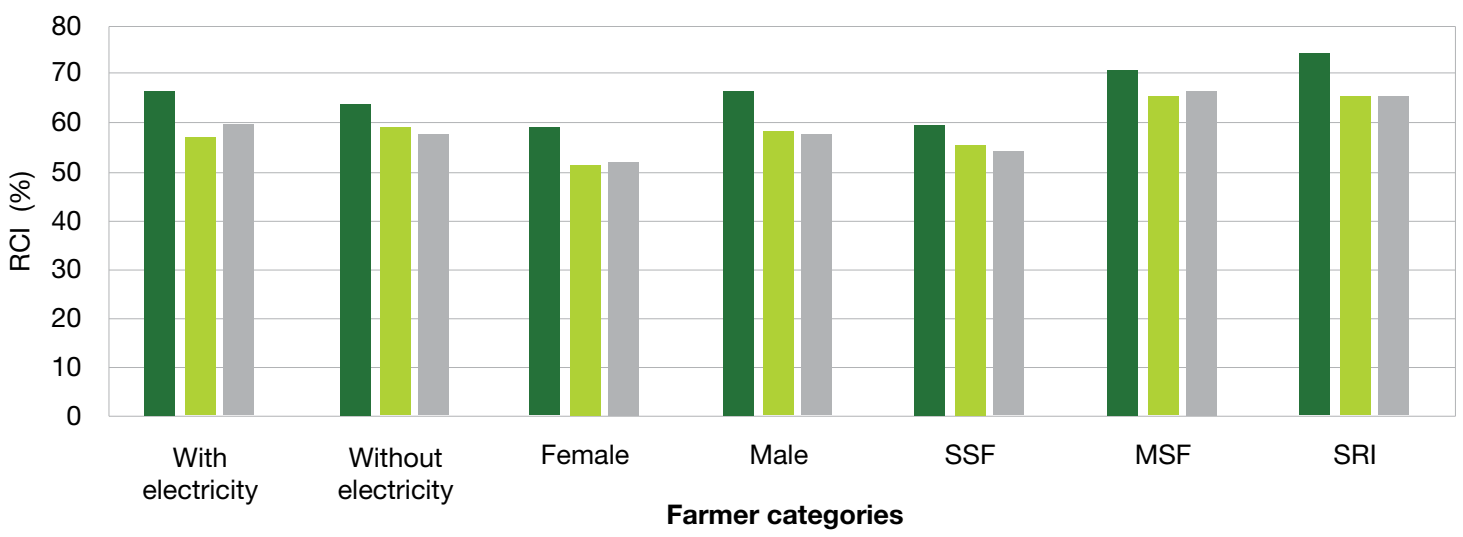

Whole sample 2017

Whole sample 2019

Panel sample 2019

Source: Authors' own 
The coefficient for non-farm income, which was practically zero during the previous wave, increased up to 0.0014 in 2019 with a positive marginal effect, implying that an increase of non-farm income by TSh100,000 (approximately US\$44) would raise the $\mathrm{RCl}$ by 0.0006 per cent. The dummy variables for MSFs and SRI members were both positive and highly significant. Their corresponding marginal effects were 0.07 and 0.06 respectively, implying that the $\mathrm{RCI}$ for MSFs and SRI members is higher by that proportion compared to that of SSFs.

Variables which had negative coefficients included the dummy for the year of data collection (-0.14), implying that the $\mathrm{RCl}$ for the year 2019 was lower than that of 2017 by 0.06 per cent. The findings further show that older farmers are less likely to commercialise due to their lower risk-taking tendencies. Larger households also scored a negative coefficient, implying lower $\mathrm{RCl}$ values. This is likely because they have more people to feed and hence less rice to sell. The coefficient for purchased seed was also negative (-0.0918). The marginal effects imply that a unit percentage increase of famers using purchased seed would reduce the $\mathrm{RCl}$ by 0.04 per cent, which is contrary to expectations. It is important to note that purchased seed in this case is not synonymous with improved seed. Over 80 per cent of rice farmers in Tanzania use local unimproved seed (Msuya et al., 2018). In most cases farmers who purchased seed from neighbours essentially purchased local seed rather than improved seed.

The negative coefficient on purchased seed is possibly related to the significant decline of $\mathrm{RCl}$ among $\mathrm{SRI}$ members who did not purchase seed in 2019 as discussed earlier (Table 3.4), probably representing the effect of discontinued credit and advisory facilitation from KPL. The coefficient for distance to the nearest large mill was also negative (-0.0004). This variable was used as a proxy for electrification. The corresponding marginal effect of -0.0002 implies that farmers who are located closer to large electric mills (unlike diesel powered mills) are likely to have higher $\mathrm{RCl}$ because they can respond to electrification via intensification as well as extensification and by selling rice/paddy at a higher price relative to their counterparts who live in remote villages. This in turn incurs higher transport costs, which lowers their farm gate price (Isinika et al., 2020). In the next section we examine how changes in commercialisation levels relate to livelihood outcomes.

Table 4.1 Determinants of $\mathrm{RCI}$ in Kilombero District: pooled fractional probit

\begin{tabular}{|c|c|c|c|c|}
\hline Variable & $\begin{array}{l}\text { Expected } \\
\text { sign }\end{array}$ & Coefficient & Robust s.e. & $\begin{array}{l}\text { Marginal } \\
\text { effect }(\mathrm{d} / \mathrm{dx} \text { ) }\end{array}$ \\
\hline Constant & $+/-$ & 0.0695 & 0.1421 & - \\
\hline Dummy year (2020=1) & $+/-$ & $-0.1457^{\star \star \star}$ & 0.0448 & -0.0573 \\
\hline Age of household head (years) & $-/+$ & $-0.0085^{\star \star \star}$ & 0.0016 & -0.0034 \\
\hline Years of schooling & + & $0.0242^{\star \star \star}$ & 0.0085 & 0.0095 \\
\hline Sex of household head (Female=1) & - & -0.0626 & 0.0597 & -0.0246 \\
\hline Household size (count) & - & $-0.0222^{\star \star \star}$ & 0.0087 & -0.0087 \\
\hline Total land (ha) & + & $0.0155^{\star \star}$ & 0.0067 & 0.0061 \\
\hline Access to extension service (1=yes) & + & $0.1374^{\star \star \star}$ & 0.0430 & 0.0540 \\
\hline Distance to rice mill (km) & - & -0.0004 & 0.0017 & -0.0002 \\
\hline Non-farm income (TSh100,000, or about US\$44) & + & $0.0014^{*}$ & 0.0008 & 0.0006 \\
\hline Use of purchased seed (1=yes) & + & -0.0918 & 0.0581 & -0.0361 \\
\hline Use of inorganic fertilisers ( $1=y e s)$ & + & $0.0986^{*}$ & 0.0546 & 0.0388 \\
\hline Use of organic fertiliser (1=yes) & + & $0.5201^{\star \star \star}$ & 0.1963 & 0.2045 \\
\hline Use of tillage services (1=yes) & + & $0.3219^{\star \star \star}$ & 0.0899 & 0.1266 \\
\hline Use of herbicides (1=yes) & + & $0.1219^{\star \star \star}$ & 0.0465 & 0.0479 \\
\hline Type of farmer dummy 1 (1=MSF) & + & $0.1824^{\star \star}$ & 0.0799 & 0.0717 \\
\hline Type of farmer dummy 2 (1=SRI) & + & $0.1461^{\star \star}$ & 0.0650 & 0.0574 \\
\hline
\end{tabular}

$\mathrm{n}=1140$; Wald $\mathrm{X}^{2}(16)=179.25, \mathrm{p}>\mathrm{X}^{2}=0.0000$; Pseudo $\mathrm{R}^{2}=0.0328$

${ }^{*}=$ significant at 10 per cent, ${ }^{\star \star}=$ significant at 5 per cent and ${ }^{* \star \star}=$ significant at 1 per cent

Source: Authors' own 


\section{LIVELIHOOD OUTCOMES}

\subsection{Descriptive analysis}

Descriptive analysis is used to compare poverty levels between farmer categories while pooled probit regression analysis is used to assess factors accounting for observed changes in livelihood indicators such as the MPI, food security status and the MDD for women of reproductive age within the sample (Table 5.1). We begin with the descriptive analysis (Figures 5.1 and 5.2), which shows that the sample mean for MPI decreased from 0.29 in 2017 to 0.19 in 2019, which lies below the poverty level cut-off point of 0.33 and is below the national mean of 0.275 for Tanzania (UNDP, 2019), representing significant livelihood improvement. The most significant decline in MPI, is observed among SRI members (-57.9 per cent) followed by MSFs (-51.4 per cent) and lowest among SSFs (-30 per cent). The decline in the proportion of MPI poor households also followed the same pattern (Figure 5.1b).

Figure 5.1 Distribution of MPI by farmer category

(a) MPI score

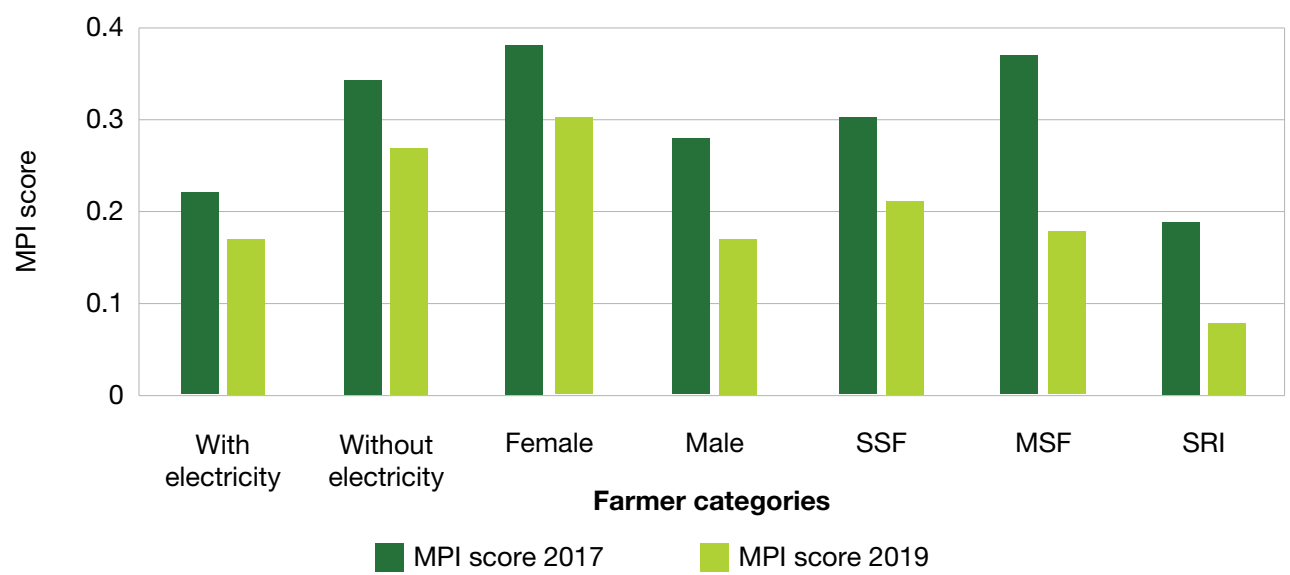

(b) Per cent of MPI poor households

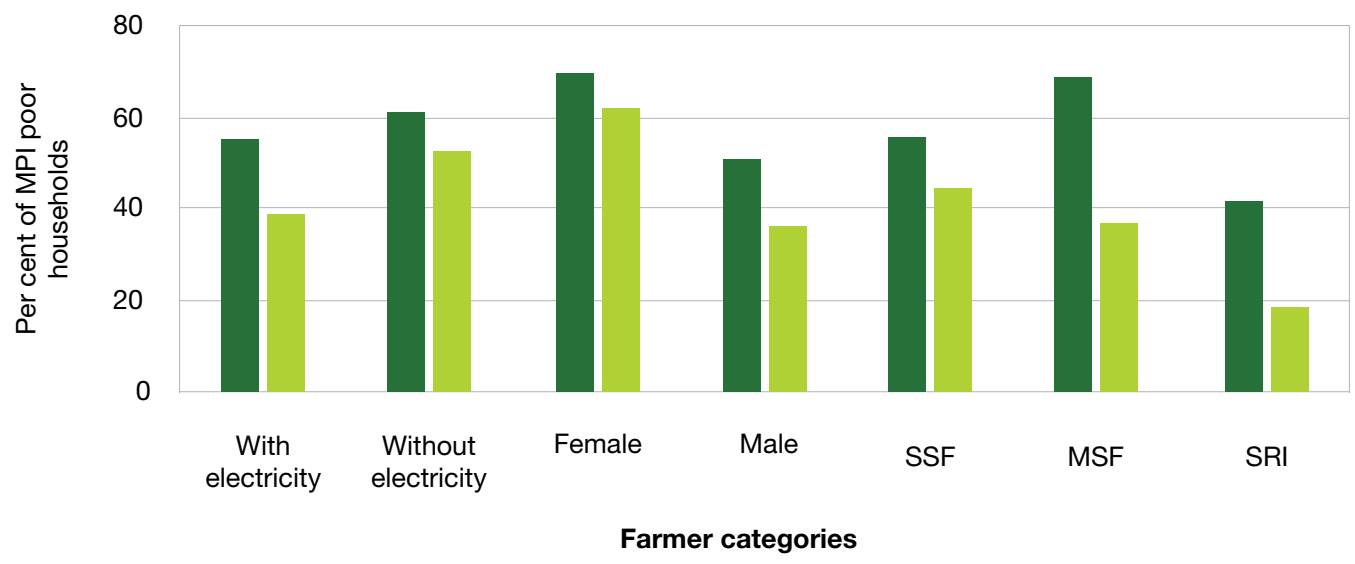


The results presented earlier (Section 3) imply that although SRI members experienced relatively higher rates of decline for input use, yield, quantity of paddy harvested and $\mathrm{RCl}$, they still maintained the highest mean yield among farmer categories and a higher median yield comparable to SSFs and MSFs (Figure 1). The SRI members also had the highest proportion of farmers using inorganic fertiliser (Table 3.5). Comparison by gender shows that $\mathrm{MHH}$ experienced a higher level of MPI decline (-39.3 per cent) as well as the highest decline in the proportion of MPI poor households (-28.1 per cent) compared to FHHs, which points to the need to improve their inclusion. A similar argument holds for farmers in villages without electricity where the MPI remains relatively high at 0.27 compared to 0.17 among famers in villages with electricity.

To address the problem of poverty in these villages, in addition to raising household income through agricultural commercialisation, a combination of institutional and infrastructure support to improve services such as water, health, education and road infrastructure is required. Cultural changes within the communities are also necessary to address some negative cultural practices and norms such as the stigma of sharing toilets across age groups or with in laws (Isinika et al., 2020) resulting in low use of toilets even where they have been constructed to meet government guidelines. The MSFs also experienced a significant decline in the proportion of MPI poor farmers (-45.8 per cent), which may be attributed to changes related to such cultural practices, such as the stigma in sharing toilet facilities across age groups (old and young) and across conjugal relations, especially sharing with in-laws. Comparison by $\mathrm{RCl}$ shows that the MPI declined for all categories except the second quantile (RCI 21-40) where the MPI increased by 11.8 per cent, implying an increase in poverty. The decline

Figure 5.2 Distribution of MPI by $\mathrm{RCI}$

(a) MPI score

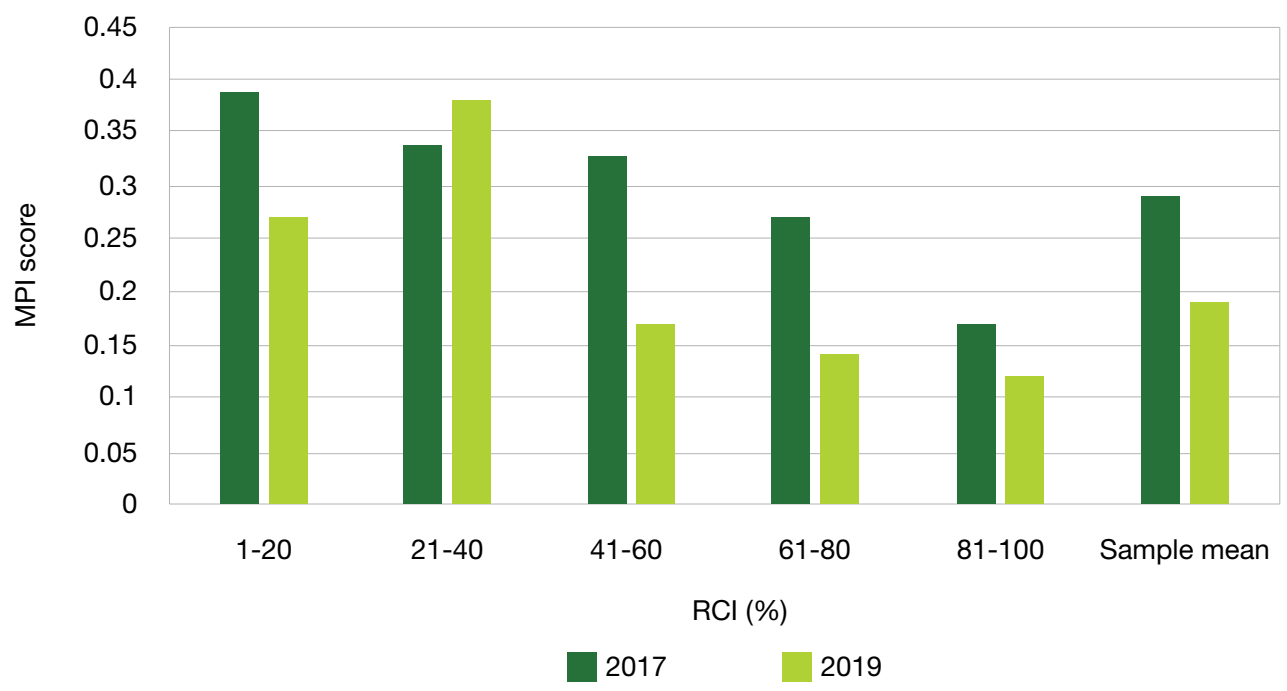

(b) Per cent of MPI poor households

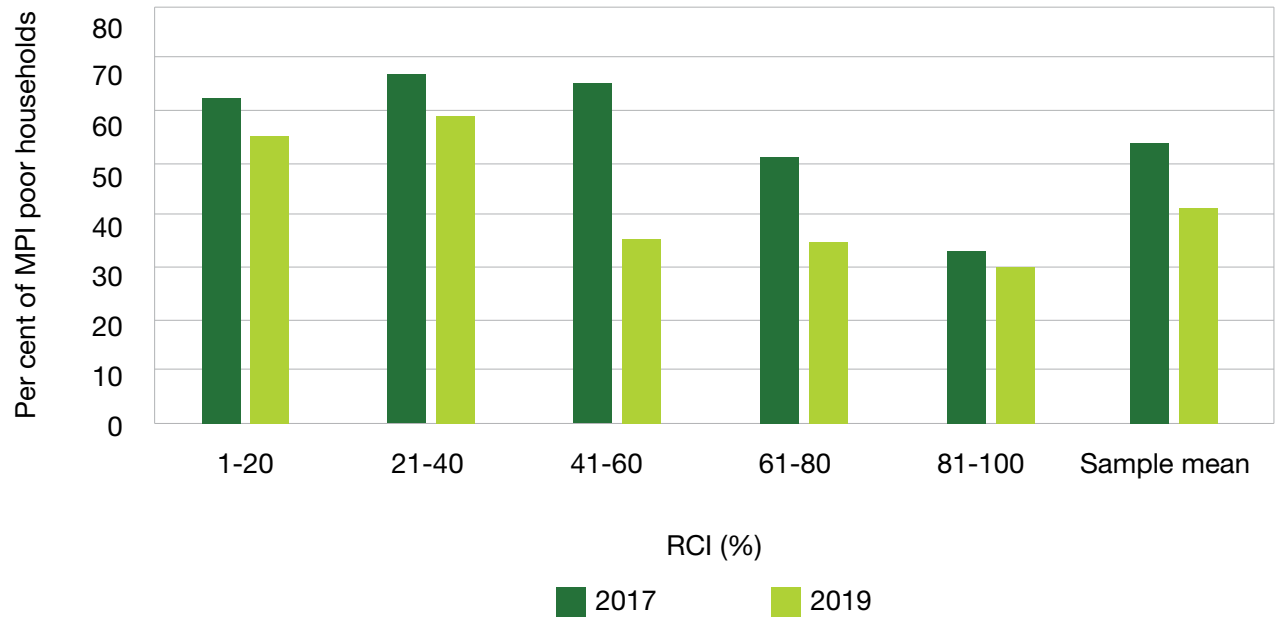

Source: Authors' own 
in MPI among farmers in the panel sample was lower, implying that for the whole sample the new entrants were relatively less MPI poor.

The results of the analysis showed a decline in MPI, representing livelihood improvement, despite a decline in rice commercialisation, which may seem puzzling. These findings suggest that other sources of income filled the gap from reduced paddy sales. To verify this, we examined the components of total household income (THHI) presented in Figure 5.3. The mean THHI (comprised of income from crops, livestock and nonfarm income) increased by 17.1 per cent from 2.48 million in 2017 to 2.92 million in 2019. Meanwhile, the median income increased by 7.8 per cent from 1.02 million to 1.09 million between the two waves.

It seems that the increase in $\mathrm{THHI}$ is driven by changes in income from crops whose mean increased by 23 per cent during the study period compared to only 5.8 per cent for non-farm income and a slight decline (-0.7 per cent) of livestock income. Comparison of mean $\mathrm{THHI}$ across farmer categories shows that SSFs had a lower increase (26 per cent) compared to MSFs and SRI members (34 and 32 per cent respectively), which explains why the SSFs had the lowest MPI decline, representing relatively lower livelihood improvement. A similar argument applies when comparison is made by gender where $\mathrm{FHH}$ s experienced only 2.7 per cent increase in $\mathrm{THHI}$ compared to 20.8 per cent for their male counterparts. Hence, FHHs experienced a lower rate of livelihood improvement as the MPI declined by only 21.1 per cent compared to 39.3 per cent of $\mathrm{MHH}$.

The increase in crop income is driven by three crops: rice, bananas and cocoa, which increased both the farmers' mean and median income. While rice is Figure 5.3 Composition of THHI

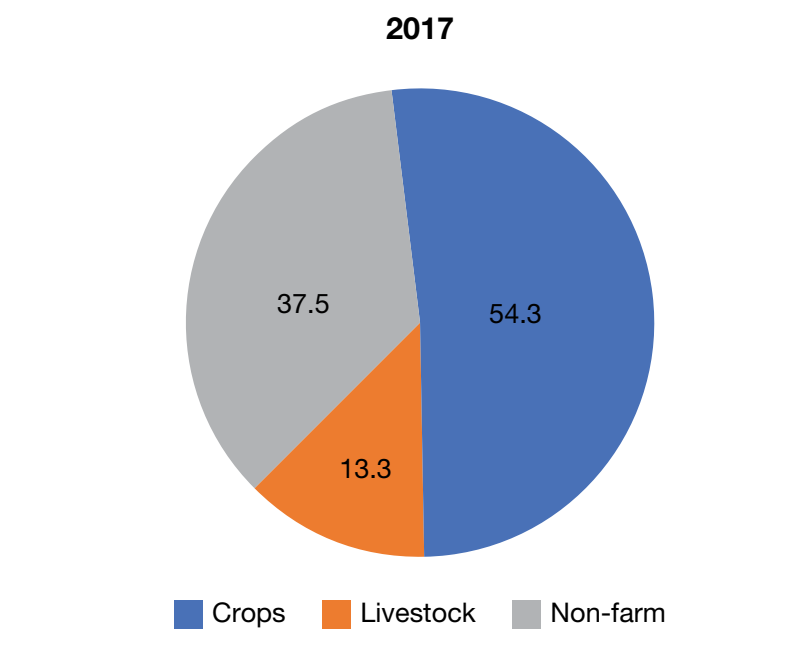

Source: Authors' own

\section{Figure 5.3 Composition of THH}

produced by over 94 per cent of the respondents, bananas and cocoa had less than 7 and 2 per cent respectively. The African Wildlife Foundation (AWF) has been promoting cocoa production in Kilombero valley as an alternative crop. Since, 2017 they have raised and distributed 320,883 seedlings, increasing the area under cocoa from 478ha in 2017 to over 1,269ha by 2021. The median of many other crops is zero implying that more than 50 per cent of the farmers did not earn any cash income from the crop. Such crops are mainly for subsistence or are minor cash crops. These include maize, groundnuts, soybeans, peas, cassava, potato, oranges, sunflowers and garlic.

Non-farm income also increased by 11.2 per cent for the whole sample but by only 1.9 per cent for the panel sample. Again, MSFs and SRI members experienced a higher rate of increase (25.1 and 26.5 per cent respectively) compared to only 16.3 per cent for SSFs. Likewise, $\mathrm{MHH}$ s reported a 14.1 per cent increase in non-farm income but $\mathrm{FHH}$ s experienced a 7.4 per cent decline. Further 22analysis of non-farm income showed that for the whole sample there was a marginal increase of 11.2 per cent even though its share of $\mathrm{THHI}$ declined by about 3.7 per cent (Figure 5.3). However, some categories of farmers (SRI members, MSFs, SSFs, MHHs) experienced a significant increase. In general, these data show that SRI members and MSFs experienced a significant increase in non-farm income, which then contributed to a significant improvement in their livelihood.

\subsection{Regression analysis}

Regression analysis was then used to assess factors which, influence the variation in livelihood outcomes (MPI, food security and MDD) as stated earlier. Findings

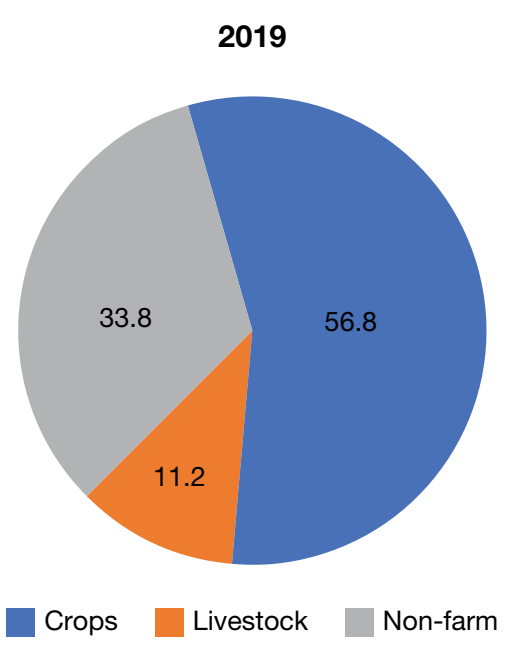


from the pooled probit model and the corresponding marginal effects are presented in Table 5.1. These findings show that the Wald Chi square values for all three models are very highly significant $(p=0.00)$, implying that the models represent good fit of the data set, hence they can be used for making statistical inference in the study area. All three models have the expected signs for all the variables. The model for MPI had the highest number of significant coefficients (11) followed by the model for food security (8) and lowest for MDD.

Variables which had a very highly significant poverty reducing effect (negative coefficient with marginal effects presented in brackets) were the year of study $(-0.13)$, years of schooling of the household head (-0.5), village having electricity (-0.08), rice yield (-0.04) and the dummy for SRI members (-0.13). The coefficient for a village having electricity was also highly significant (- 0.08) indicating a strong significant association between a village having electricity and poverty reduction, while the dummy for MSFs was also significant (-0.12). The coefficients for area under rice and total household income are also negative (-0.0049 and -0.0001 respectively) but their influence on poverty reduction was not significant. Meanwhile, FHHs and large households had a significant poverty increasing effect. The coefficient for age $(+0.0049)$ was also positive but its effect on increasing poverty of older farmers was not significant. Rice commercialisation had a significant influence on reducing poverty only for the fifth quintile. The coefficients for the third and fourth quantiles were also negative (-0.0902 and -0.1663 respectively) but their influence on poverty reduction was not significant. However, the coefficient for the second quintile had a significant positive coefficient $(+0.3141 \mathrm{p}<0.1)$ implying that farmers in the second quintile were likely to be poorer compared to farmers in the first quintile who were less commercialised. At such low commercialisation levels, farmers probably engage in distress sale of paddy (Isinika et al., 2020) whereby they only sell because they are in dire need to meet other urgent household needs such as sickness in the family or to buy other food types. Gasnner et al.

Table 5.1 Determinants of welfare outcomes: pooled probit results

\begin{tabular}{|c|c|c|c|c|c|c|}
\hline \multirow[t]{3}{*}{ Variable } & \multicolumn{6}{|c|}{ Type of welfare outcome } \\
\hline & \multicolumn{2}{|c|}{ MPI } & \multicolumn{2}{|c|}{ Food security status } & \multicolumn{2}{|c|}{ MDD } \\
\hline & Coefficient & Robust s.e & Coefficient & Robust s.e & Coefficient & Robust s.e \\
\hline Constant & $0.6983^{\star \star}$ & 0.2906 & -0.2737 & 0.2901 & 0.0670 & 0.2714 \\
\hline Year dummy (1=2020) & $-0.3241^{\star \star \star}$ & 0.0978 & $0.2321^{\star \star}$ & 0.1011 & $-0.3468^{\star \star \star}$ & 0.0968 \\
\hline Age of household head (years) & 0.0049 & 0.0033 & -0.0018 & 0.0034 & -0.0033 & 0.0033 \\
\hline $\begin{array}{l}\text { Years of schooling of } \\
\text { household head }\end{array}$ & $-0.1270^{\star \star \star}$ & 0.0186 & $0.0706^{\star \star \star}$ & 0.0178 & $0.0327^{\star \star}$ & 0.0164 \\
\hline $\begin{array}{l}\text { Sex of household head } \\
\text { (1=female) }\end{array}$ & $0.5087^{\star \star \star}$ & 0.1216 & $-0.3734^{\star \star \star}$ & 0.1160 & -0.1652 & 0.1117 \\
\hline Household size (count) & $0.0741^{\star \star \star}$ & 0.0185 & -0.0002 & 0.0195 & -0.0003 & 0.0182 \\
\hline $\begin{array}{l}\text { Electricity status of village } \\
\text { (1=yes) }\end{array}$ & $-0.2106^{\star \star}$ & 0.1037 & -.1092 & 0.1059 & 0.1648 & 0.1029 \\
\hline Rice area (ha) & -0.0049 & 0.0129 & -0.0012 & 0.0186 & 0.0023 & 0.0114 \\
\hline Rice yield (t/ha) & $-0.0898^{\star \star \star}$ & 0.0333 & $0.0792^{\star \star}$ & 0.0400 & 0.0331 & 0.0238 \\
\hline $\begin{array}{l}\text { THHI (TSh100,000 about } \\
\text { US\$44) }\end{array}$ & -0.0001 & 0.0008 & 0.0006 & 0.0011 & -0.0009 & 0.0008 \\
\hline $\mathrm{RCl}$ quintile dummy 1 (1=Q2) & $0.3141^{\star}$ & 0.1701 & -0.1171 & 0.1616 & 0.0174 & 0.1573 \\
\hline $\mathrm{RCl}$ quintile dummy 2 (1=Q3) & -0.0902 & 0.1493 & $0.2682^{*}$ & 0.1450 & $0.3166^{\star \star}$ & 0.1400 \\
\hline $\mathrm{RCl}$ quintile dummy 3 (1=Q4) & -0.1663 & 0.1485 & $0.4090^{\star \star \star}$ & 0.1455 & $0.4968^{\star \star \star}$ & 0.1395 \\
\hline $\mathrm{RCl}$ quintile dummy 4 (1=Q5) & $-0.2559^{\star}$ & 0.1672 & 0.2500 & 0.1656 & 0.0842 & 0.1543 \\
\hline Farmer type dummy 1 (1=MSF) & $-0.3132^{\star}$ & 0.1667 & $0.6300^{\star \star \star}$ & 0.2091 & $0.3097^{*}$ & 0.1643 \\
\hline \multirow[t]{2}{*}{ Farmer type dummy 2(1=RCl) } & $-0.3303^{\star \star \star}$ & 0.1255 & $0.2253^{\star}$ & 0.1134 & 0.1035 & 0.1249 \\
\hline & \multicolumn{2}{|c|}{$\begin{array}{l}n=1048, \text { Wald } X^{2}(15)=178.3 \\
p>X^{2}=0.000, \text { Pseudo } \\
R^{2}=0.0328\end{array}$} & \multicolumn{2}{|c|}{$\begin{array}{l}n=1051, \text { Wald } X^{2}(15)=97.4 \\
p>X^{2}=0.000, \text { Pseudo } \\
R^{2}=0.0859\end{array}$} & \multicolumn{2}{|c|}{$\begin{array}{l}n=1051, \text { Wald } X^{2}(15)=97.4 \\
R^{2}>X^{2}=0.000, \text { Pseudo } \\
R^{2}=0.0859\end{array}$} \\
\hline
\end{tabular}

${ }^{*}=$ significant at $10 \%,{ }^{* *}=$ significant at $5 \%$ and ${ }^{* \star *}=$ significant at $1 \%$

Source: Authors' own 
(2019) attribute this to the challenge of mixing food and income targets at this level.

The interpretation of coefficients for the food security model is different. Here a positive sign implies improved food security while a negative sign indicates the opposite effect. Food security for 2019 was higher than that of 2017 with a marginal effect of -0.08 . Food security was positively and significantly influenced by years of schooling of the household head, rice yields and the commercialisation level. Negative effects on food security came from several factors including: FHHs, which were significantly more likely to be food insecure compared to their male counterparts. As already stated under the descriptive analysis, these households face various resource constraints including land, due to cultural constraints since land is inherited through the male lineage. $\mathrm{FHHs}$ also face labour and income constraints due to their composition, often falling short on male labour and earning lower incomes than their male counterparts on average, due to lower agricultural productivity, lower return on nonfarm activities and less employment opportunities. Hence, they often fail to access the required quantities of purchased inputs. Consequently, they produce less marketable surplus due to lower yields and total production and are therefore more likely to be food insecure. Food security is also likely to decline for older household heads, FHHs, for households in villages with electricity, as the farm size increases and for the first quintile of the commercialisation index. This decrease in food security for villages with electricity is due to the higher proportion of farmers with small farms, as such villages are more densely populated (semi-urban) and thus face more pressure on land. Farmers who own small farms may, therefore, fail to produce enough to meet family needs. Meanwhile, the negative coefficient on farm size was explained by key informants as relating to cultural factors, where some of the farmers (primarily the customary residents, whose main economic activity was fishing) tend to sell the majority of the farm produce, leaving their families vulnerable to food insecurity before the next harvest.

The MDD measures the mean daily intake of predefined food groups among female members of childbearing age within a household. The MDD coefficient was lower in 2019 compared to 2017, implying a deterioration in food security among female members of child-bearing age within households. This variable was significantly positively influenced by the years of schooling of the household head and the level of commercialisation. Other positive factors on MDD included electricity in a village, area under rice, yield and $\mathrm{THHI}$. Meanwhile, households headed by older members and $\mathrm{FHH}$ sere significantly more likely to face less dietary diversity of their female members. $\mathrm{THHI}$ was also negatively associated with lower MDD. This finding may seem controversial, but it is consistent with earlier findings (Isinika et al., 2020) where it was established that the majority of MSFs earned high incomes but also faced higher poverty levels due to challenges they still faced. For example, most MSFs tend to live in remote villages where land is available for farm expansion but access roads as well as access to education, water and health services are poorer, and female empowerment is lower. Where women are empowered, households tend to have improved nutrition, food security and less deprivation of children attending school (Jeckoniah and Kilave, 2020).

\subsection{Self-assessment}

The findings reported in the preceding sections conform to the famers' self-assessment of their livelihood status. While such assessment reflected more optimism than the formal indicators, self-assessment represents the respondents' perception, which influences how they are likely to use their resources to improve their conditions. Comparison between the two waves shows that SSFs represented the highest level of optimism, showing a decline in all categories of poverty with corresponding improvement in all categories of wealth and wellbeing (Annex 4). However, there was an increase in the proportion of SSFs who felt they never had quite enough and those who felt they were destitute, representing SSFs who had stepped-down. The proportion of SSFs who were poor did not change, representing stagnation.

Self-assessment among MSFs reflects both steppingup and stepping-down. There was an increase in the proportion of farmers who considered themselves among the richest, probably coming from farmers who had previously classified themselves as richer than most and above average, whose proportion declined by 10.3 and 0.5 per cent respectively. However, famers who felt they were among the poorest in the village increased by 61.1 per cent. This corresponded with an increase in the proportion of farmers who reported that they never had quite enough to meet their needs as well as those who felt they were poor. None of the respondents felt they were destitute. Meanwhile, self-assessment by SRI members represented more optimism (Annex 4). Comparison by gender showed that a decline in the perceived wealth status was experienced by both $\mathrm{MHH}$ and $\mathrm{FHHs}$. However, the $\mathrm{FHH}$ represented a group that experienced stepping down into lower wealth ranks in 2019 compared to 2017, increasing the proportion of farmers who felt they 
were poorest in the village and those who never had enough to meet their needs (Annex 4).

\subsection{Sources of livelihood improvement}

In order to understand the sources of livelihood improvement (poverty reduction), which reflect the optimistic stance presented by most of the respondents, the study examined how the components of the MPI indicator have changed between the two waves, discerning similarities and differences in the farmers' perception and their response thereof. The variables that constitute the MPI include: (i) food security, (ii) health and nutrition and (iii) child mortality during the last 12 months. Other factors were: (iv) children of school age being out of school, (v) years of schooling for those who had missed school during their childhood up to the age of five years and (vi) quality of housing currently, which included flooring, sanitation, cooking fuel, electricity and drinking water.

While cash income is necessary for livelihood improvement, there is no assurance of cause and effect because livelihood improvement within a household also depends on how that income is used. Analysis of poverty indicators that constitute the MPI, are reported in Table 5.2. For the whole sample, households that experienced the most significant livelihood improvement were observed to have reduced deprivation in four key areas: (i) sanitation (-18.3 per cent), (ii) the quality of the house floor (-11.2 per cent), (iii) children deprived of school (-10.7 per cent) and (iv) access to electricity (-9.2 per cent). We noted earlier that MSFs and SRI members experienced the most improvement in livelihood corresponding to MPI decline. In the case of SRI members most of the improvement was associated with improved access to electricity, improved sanitation and food security. Meanwhile, for MSFs livelihood improvement was associated with a significant decline in the proportion of households that had children deprived of education (-31.3 per cent), the quality of house floor (-8.2 per cent), improved sanitation (25.7 per cent) and access to electricity (-23.3 per cent).

Comparison by gender showed that $\mathrm{MHH}$ s experienced improvement in all livelihood indicators except assets where the proportion of deprived households increased. Meanwhile, FHHs experienced increased deprivation in three areas; access to electricity, cooking fuel and assets. In relation to commercialisation, we note that categories of farmers that had improved livelihood may not have experienced the highest improvement in household income but rather spent their income on improving amenities, which had previously placed them at lower wealth ranks.

In addition to income and changes in spending priorities, these improvements can also be explained by changes in attitude, especially among agropastoralists who recorded higher rates of livelihood improving indicators such as having electricity, improved house flooring, improved sanitation and sending children to school (Table 5.2). The bottom line is, livelihood improvement earned from agricultural commercialisation and other sources also depends on how a household spends their income. During a stakeholders' feedback meeting in the study area, it was pointed out that social networks as well as campaigns to raise awareness about negative cultural practices are important. They are complemented by institutional and infrastructure improvement as discussed in relation to findings for the first wave (Isinika et al., 2020).

Table 5.2 Sources of livelihood (MPI) improvement

\begin{tabular}{|l|l|l|l|l|l|l|}
\hline \multirow{2}{*}{ Indicator of livelihood } & \multicolumn{5}{|c|}{ \% change in MPI livelihood indicators } \\
\cline { 2 - 7 } & Sample & SSF & MSF & SRI & Female & Male \\
\hline Food insecure & -4.1 & -3.3 & -6.2 & -2.9 & -1.8 & -5.4 \\
\hline Health and nutrition (child mortality) & -3.1 & -3.8 & 5.6 & 9.4 & -3.1 & -3.2 \\
\hline School age of children out of school & -10.7 & -8.2 & -31.3 & -23.1 & -13.9 & -10.3 \\
\hline Years of schooling (None had $\geq 5$ years) & -3.2 & -3.7 & -8.5 & -4.8 & -5.4 & -3.1 \\
\hline House floor & -11.2 & -12 & -28.2 & -16.2 & -6 & -12.4 \\
\hline Sanitation & -18.3 & -19.5 & -25.7 & -6.2 & -6.6 & -20.2 \\
\hline Cooking fuel & -1.4 & -0.8 & -9.6 & -8.8 & 0.6 & -4.8 \\
\hline Electricity & -9.2 & -6.3 & -23.3 & -17 & 6.9 & -9.1 \\
\hline Drinking water & -0.8 & -0.8 & -9.9 & -9.1 & -6.6 & -5.9 \\
\hline Assets & 4.5 & 3.5 & -2.2 & -5.7 & 2.4 & 10.5 \\
\hline
\end{tabular}

Source: Authors' own 
The purpose of this paper was to assess differential outcomes from rice commercialisation options for different categories of farmers. Using data collected in two waves (2017 and 2019) from Mngeta Division in Kilombero District, Tanzania, this study aimed to identify factors that may account for exclusion in rice commercialisation, especially among women and girls, and the corresponding livelihood impacts. The analysis sought to assess changes experienced by different categories of farmers in the use of inputs and services, productivity and commercialisation outcomes as well as livelihood impacts. Comparison across farmer categories was made between (i) $\mathrm{FHHs}$ and $\mathrm{MHHs}$, (ii) SSFs, MSFs and SRI members, and (iii) farmers in villages with and without electricity. The inclusion of youths was also addressed using age for comparison.

Comparison between the two waves as presented in this paper clearly showed a marginal decline in the $\mathrm{RCl}$, which has been attributed to reduced land area planted with rice associated with only a marginal increase in the use of some inputs and services (inorganic fertiliser, tillage services and hired labour) and a decrease in others. Most notably, there was a decrease in the proportion of farmers using purchased seed and organic fertiliser, but the proportion of farmers using both inputs was small, limited by availability and affordability. However, there was a highly significant increase in the use of herbicides, mobile money and extension services.

Regarding exclusion trends for input use, the findings showed that $\mathrm{FHHs}$ experienced a decline in land planted with rice while $\mathrm{MHH}$ s experienced an increase in the same. Nevertheless, there was a substantial increase among $\mathrm{FHHs}$ who used inorganic fertiliser, herbicides and mobile money services, even though their proportion remained lower than that of $\mathrm{MHHs}$. These changes indicate that $\mathrm{FHHs}$ are catching up in the use of these inputs and services, which is positive for inclusion and can be attributed to increasing access to extension services and non-farm income, enabling them to purchase more inputs and services and hence step-up commercialisation. Meanwhile, FHHs remain relatively disadvantaged as they face more challenges to find less opportunities for improving their position both in farming and in other nodes of the value chain as traders, processors or service providers in transportation and supplying agricultural inputs, hence they tend to benefit less from rice commercialisation. The FHHs experienced a decline in paddy yield while $\mathrm{MHH}$ paddy yields increased.

The combined effect of reduced area under rice and mixed changes in input use translated in $\mathrm{FHHs}$ harvesting and selling significantly lower volumes of paddy/rice compared to their $\mathrm{MHH}$ counterparts. The $\mathrm{FHHs}$ experienced a significant decline in $\mathrm{RCl}$ while that of MHHs stagnated, which demonstrates the former's exclusion, despite efforts to enable then to catch up through extension services for example. Resource constraints such as land, labour and capital remain major limitations for women's inclusion in agricultural commercialisation because as argued earlier (Section 5.2), land is inherited through the male lineage, limiting women's access to this critical resource in agriculture. Labour constraints arise due to the composition of FHHs while access to capital is limited due to various factors including lack of collateral. Other categories of farmers which experienced a decline in commercialisation included SRI members, who lost credit facilitation and advisory services that were previously provided by KPL.

The descriptive findings are consistent with regression analysis which showed that variation in $\mathrm{RCl}$ was positively influenced by years of schooling, total land owned, use of fertiliser (inorganic and inorganic) and access to tillage and extension services. Both MSFs and $\mathrm{SRI}$ members were more likely to have higher $\mathrm{RCI}$ than SSFs. Meanwhile, the RCl was negatively influenced by the age of the household head, household size and $\mathrm{FHH}$ s were more likely to have lower $\mathrm{RCl}$ than $\mathrm{MHH}$.

Despite the observed marginal decline in commercialisation, the analysis showed a significant improvement in livelihood represented by a decline in the MPI as well as improvement in food security and MDD for women of childbearing age within all households. The most significant decline was experienced by MSFs and SRI members. This also corresponded to a significant decline in the proportion of MPI poor households, especially among MSFs and SRI members. Comparison by gender showed a lower level of poverty decline among FHHs compared to 
MHHs. The improvement in livelihood was attributed to an increase in $\mathrm{THH}$, which was driven by crop incomes. Since both the volume and value of rice harvested declined slightly in 2019 relative to 2017, the increase in $\mathrm{THHI}$ came from diversification into other crops, especially bananas, cocoa and oil palm. From 2017, the AWF has been promoting cocoa and raising seedlings for distribution to farmers to reduce the demand for natural resources (timber, fuel wood, vegetables) from the neighbouring Udzungwa Mountain National Park, a home to some endemic birds, plants and animals.

The increased income has been used to improve livelihood factors that previously placed households at lower wealth ranks. The analysis showed that while rice commercialisation contributes significantly to livelihood improvement in the study area, it is complemented by income from other crops, livestock and from non-farm sources. Overall, our study shows that diversification complemented by facilitation from the government and other development agencies to improve infrastructure and market and governance institutions are important drivers that lead to poverty reduction. The second key finding from this study is that a gender gap is still recorded in input use, yields, rice commercialisation and livelihood indicators. This means that women are still being excluded from rice commercialisation and are still not receiving equal access to important agricultural resources. More needs to be done by way of direct facilitation, which specifically targets women, young girls and youths including interventions to ensure their access to capital through mechanisms such as government loan guarantees and ensuring remittance of 4 per cent of LGA revenue to the Women and Youth Development Fund. In addition, there should be deliberate efforts to improve the inclusion of women's and youths' access to irrigation and extension services through deliberate targeting and quotas for their minimum level of participation. As pointed out earlier, women account for approximately 43 per cent of the world's agricultural labour force. In Tanzania, women represent approximately 54 per cent of the agricultural labour force and the majority of women derive their income from agriculture. If women were empowered to have the same access to resources as men, a higher proportion of households would experience poverty reduction 
Ajani, E.N. and Egbokwe, E.M. (2013) 'Occupational diversification among rural women in Sub-Saharan Africa: A review', African Journal of Food, Agriculture, Nutrition and Development 13(5): 8224-8237

Chirwa, E.W., Dorward, A. and Matita, M. (2011). Initial conditions and changes in commercial fertilizers and the farm input subsidy programme in Malawi: Implications for graduation. FAC Working Paper 30. Brighton: Future Agricultures Consortium. Available at: https://opendocs.ids.ac.uk/opendocs/bitstream/ handle/20.500.12413/2253/ (Accessed 19 August 2021)

Mdee, A., Ofori, A., Chasukwa, M. and Manda, S. (2020) 'Neither sustainable nor inclusive: a political economy of agricultural policy and livelihoods in Malawi, Tanzania and Zambia', The Journal of Peasant Studies p1-24. Available at: https://doi.org/10.1080/03066150.2019.1708724 (Accessed: 25 March 2021)

Alkire, S., Conconi, A., Robles, G., Roche, J. M, Santos, M.E., Seth, S. and Vax, A. (2016) The Global Multidimensional Poverty Index (MPI): 5-year Methodological Note, OPHI Briefing Note 38, London: University of Oxford. Available at: https://www.ophi.org.uk/wp-content/uploads/OPHIBrief_38.pdf (Accessed: 10 February 2019)

Djurfeldt, A.A., Djurfeldt, G., Hillbom, E., Isinika, A.C., Joshua, M.D.K., Kaleng'a, W.C., Kalindi, A., Msuya, E., Mulwafu, W. and Wamulume, M. (2019) 'Is There Such a Thing as Sustainable Agricultural Intensification in Smallholder-based Farming in Sub-Saharan Africa? Understanding Yield Differences in Relation to Gender in Malawi, Tanzania and Zambia', Development Studies Research 6(1): 62-75. Available at: https://doi.org/10.1080/2 1665095.2019.1593048 (Accessed: 25 March 2021)

Djurfeldt, A. and Hillbom, E. (2016) 'Pro-poor Agricultural Growth-Inclusion or Differentiation? Village Level Perspectives from Zambia', Journal of Physical, Human, and Regional Geosciences 75: 220-233

Dorward, A. (2009) 'Integrating Contested Aspirations, Processes and Policy: Development as Hanging In, Stepping Up and Stepping Out', Development Policy Review 27(2): 131-146

Doss, C. R. (2001) 'Designing Technologies for African Women Farmers: Lessons from 25 years of experience' World Development 28(7): 1341-1345

Doss, C.R. and Morris M.L. (2021) 'How does gender affect the adoption of agricultural innovations? The case of improved maize technology', Agricultural Economics 25: 37-39

Finscope Tanzania (2017) Insights that drive innovation. Dar es Salaam: Financial Sector Deepening Trust. Available at: https://www.fsdt.or.tz/wp-content/uploads/2017/09/FinScope-Tanzania-2017-Insights-that-DriveInnovation.pdf (Accessed: 26 February 2020)

Gasnner, A., Harris, D., Masch, K., Terheggen, A., Lopez, C., Finlayson, R.F. and Dobie, P. (2019) 'Poverty eradication and food security through agriculture in Africa: Rethinking objectives and entry points', Outlook on Agricuture 2019 48(4): 309-315

Gupta, S., Vemireddy, V. and Pingali, P.L. (2019) 'Nutritional outcomes of empowerment and market integration for women in rural India', Food Security 11: 1243-1256

Idris I. (2018) Mapping women's economic exclusion in Tanzania. K4D Knowledge Evidence and Learning for Development. GSDRC, University of Birmingham 11 May 2018. Avaliable at https://assets.publishing.service. gov.uk/media/5b18ff6f40fOb634d557af84/Mapping_Womens_Economic_Exclusion_in_Tanzania.pdf (accessed on 19.08.2021) 
Isinika, A. Mlay, G., Boniface, G. Mdoe, N. Poulton, C. and Saha, A. (2020) Does Rice Commercialisation impact on Livelihoods? Experience from Mngeta in Kilombero District, Tanzania. APRA Working Paper 30, Brighton: Future Agricultures Consortium. Available at: https://www.future-agricultures.org/publications/working-papersdocument/working-paper-30-does-rice-commercialisation-impact-on-livelihood-experience-from-mngeta-inkilombero-districttanzania/ (Accessed: 28 March 2021)

Jeckoniah, J., Mosha, D.B. and Boniface, G. (2020). Does Rice Commercialisation Empower Women? Experience From Mngeta Division in Kilombero District, Tanzania. APRA Working Paper 34, Brighton: Future Agricultures Consortium. Available at: https://opendocs.ids.ac.uk/opendocs/handle/20.500.12413/15521 (Accessed 28 March 2021)

Jayne, T.S., Chamberlin, J., Traub, L., Sitko, N., Muyanga, M., Yeboah, F.K., Anseeuw, W., Chapoto, A., Wineman, A., Nkonde, C. and Kachule, R. (2016) 'Africa' Changing Farm Size Distribution Patterns: The Rise of Medium Scale Farms', Agricultural Economics 47(2016): 197-214

Katega, I.B. and Lufiliro, C.S. (2014) Rural Non-farm Activities and Poverty Alleviation in Tanzania: A case study of Two Villages in Chamwino and Bahi District of Dodoma Region. REPOA Working Paper 14/4. Dar es Salaam: REPOA

Kato, F. (2007) 'Development of a Major Rice Producing Area in Kilombero Valley, Tanzania', African Study Monograph 36: 3-18

Khamaldin, M., Wiggins, S. and Mdoe, N. (2013) Commercialisation of African Smallholder Farming: The Case of Smallholder Farmers in Central Tanzania, APRA Working Paper 72, Brighton: Futures Agriculture Consortium. Available at: https://www.gov.uk/research-for-development-outputs/fac-working-paper-72-commercialisationof-african-smallholder-farming-the-case-of-smallholder-farmers-in-central-tanzania (Accessed: 12 April 2021)

Kirui, O.I. and Njiraini, G.W. (2013) Determinants of Agricultural Commercialization Among the Rural Poor: Role of ICT and Collective Action Initiatives and Gender Perspective in Kenya, Paper presented at 4th Conference of African Association of Agricultural Economics (AAAE), Diar Lemdina Hotel - Hammamet, Tunisia 22-25 September 2013

Koutsouris, A.A., Chenb, D., and Lyona, S.W. (2016). 'Comparing global precipitation data sets in eastern Africa: a case study of Kilombero valley, Tanzania', International Journal of Climatology, 36: 200-214

Louw, A., Ndanga, L., Chikazunga, D. and Jagwe, J. (2008) Restructuring Food Markets in the Southern African Region: Dynamics in the Context of the Fresh Produce Sub-Sector: A Synthesis of Country Findings, London: IIED

Mdoe, N., Mlay G., Isinika A., Boniface G. and Magomba C. (2020) Effect of Choice of Tillage Technology on Commercialisation and Livelihood of Smallholder Farmers in Mngeta Division, Kilombero District, APRA Working Paper, 37, Brighton: Futures Agriculture Consortium. Available at: https://opendocs.ids.ac.uk/opendocs/ handle/20.500.12413/15664 (Accessed: 22 April 2021)

Mmasa J.J. (No date) Participation of women in agriculture in Tanzania: Challenges and policy recommendations. Policy brief No.0. CLKnet (Tanzania country level knowledge network). Available at: https://www.researchgate. net/publication/271074858_WOMEN-PARTICIPATION-IN-AGRICULTURE-IN-TANZANIA_FV (Accessed 19 August 2021)

Msuya, E., Isinika, A.C. and Dzanku, F.M. (2018) 'Agricultural Intensification Response to Agricultural Input Subsidies in Tanzania: A Spatial-Temporal and Gender Perspective, 2002-15', in Djurfeldt, A.A., Dzanku, F.M. and Isinika, A.C. (ed.), Agriculture, Diversification, and Gender in Rural Africa: A Longitudinal Perspective from Six Countries. Oxford: Oxford University Press

Ombakah, E.P.J. (2014). Role of Women's Non-farm income generating activities to household food security: Case of Bagamoyo District. Unpublished M.Sc. Dissertation, Sokoine University of Agriculture

Ogutu, S.O. and Quaim, M. (2018) Commercialization of the Small Farm Sector and Multidimensional Poverty. Global Food Discussion Papers No. 117, Universität Göttingen, Research Training Group (RTG) 1666, Göttingen: Global Food 
Pingali, P., Aiyar, A., Abraham, M. and Rahaman, A. (2019) 'Enabling Smallholder Prosperity Through Commercialization and Diversification', in Pingali, P. Aiyar, A., Abraham, M. and Rahamn, A. (ed.). Transforming Food Systems for a Rising India, Palgrave Studies, Agricultural Economics and Food Policy, Cham: Palgrave Macmillan

Poulton, C. (2017) What is Agricultural Commercialisation? And How Do We Measure It? APRA Working Paper 6 , Brighton: Future Agricultures Consortium. Available at: https://www.future-agricultures.org/publications/workingpapers-document/what-is-agricultural-commercialisation-why-is-it-important-and-how-do-we-measure-it/ (Accessed: 15 January 2020)

Poulton, C. and Chinsinga, C. (2018) The Political Economy of Agricultural Commercialisation in Africa, APRA Working Paper 16, Brighton: Future Agricultures Consortium. Available at: https://opendocs.ids.ac.uk/opendocs/ handle/20.500.12413/14027 (Accessed: 23 April 2021)

Sen, A. (1999) 'The Possibility of Social Choice,' The American Economic Review 89(3): 349-378

UNDP (2019) Global Multidimensional Poverty Index 2019: Illuminating Inequalities, United Nations Development Programme. New York: United Nations Development Programme

Verma, B.N. and Verma, N (1995) 'Distress Diversification from Farm to Non-farm Rural Employment in the Eastern Region', Indian Journal of Agricultural Economics 50(3): 422-430

Wiggins, S., Argwings-Kodhek, G., Gebreselassie, S., Asuming-Brempong, S., Chirwa, E., Matita, M.M., Mode, N. and Mutabazi, K. (2014) Cautious Commercialisation. Findings from Village Studies in Ethiopia, Ghana, Kenya, Malawi and Tanzania. FAC Working Paper 82, Brighton: Future Agricultures Consortium. Available at: https:// assets.publishing.service.gov.uk/media/57a089aae5274a31e00001e6/FAC_Working_Paper_082.pdf (Accessed: 27 April 2021)

Wineman A., Jayne T., Modamba E. and Holgar K. (2020) 'The changing face of agriculture in Tanzania: Indicators of transformation', Development Policy Review 38: 685-709. Available at: https://onlinelibrary.wiley.com/doi/ full/10.1111/dpr.12491 (Accessed: 16 June 2021) 


\section{ANNEXES}

Annex 1 Sampling distribution for wave 1 and 2 by village and sex of household head

\begin{tabular}{|c|c|c|c|c|c|c|c|c|c|c|}
\hline \multirow[t]{3}{*}{ Village } & \multicolumn{5}{|c|}{2017} & \multicolumn{5}{|c|}{2019} \\
\hline & \multicolumn{2}{|c|}{ Female } & \multicolumn{2}{|c|}{ Male } & \multirow{2}{*}{\begin{tabular}{|l} 
Total \\
$\mathrm{N}$
\end{tabular}} & \multicolumn{2}{|c|}{ Female } & \multicolumn{2}{|c|}{ Male } & \multirow{2}{*}{\begin{tabular}{|l} 
Total \\
N
\end{tabular}} \\
\hline & N & $\%$ & N & $\%$ & & N & $\%$ & N & $\%$ & \\
\hline Njage & 3 & 6.2 & 45 & 93.8 & 48 & 11 & 14.5 & 65 & 85.5 & 76 \\
\hline Mkusi & 12 & 27.3 & 32 & 72.7 & 44 & 18 & 22.2 & 63 & 77.8 & 81 \\
\hline Mchombe & 9 & 13.4 & 58 & 86.6 & 67 & 16 & 15.1 & 90 & 84.9 & 106 \\
\hline Nakaguru & 7 & 10.9 & 57 & 89.1 & 58 & 5 & 5.5 & 86 & 94.4 & 91 \\
\hline ljia & 7 & 10.9 & 57 & 89.1 & 64 & 9 & 11.7 & 68 & 88.3 & 77 \\
\hline Luvilikila & 4 & 7.7 & 48 & 92.3 & 52 & 11 & 17.5 & 52 & 82.5 & 63 \\
\hline Itongoa & 5 & 11.1 & 40 & 88.9 & 45 & 17 & 18.7 & 74 & 81.3 & 91 \\
\hline Mngeta & 7 & 11.1 & 56 & 88.9 & 63 & 13 & 16.9 & 64 & 83.1 & 77 \\
\hline Makutano & 9 & 21.4 & 33 & 88.9 & 52 & 10 & 14.7 & 58 & 85.3 & 68 \\
\hline Chita & 8 & 14.8 & 46 & 85.2 & 54 & 12 & 15.6 & 65 & 84.4 & 77 \\
\hline Sample total & 66 & 12.3 & 471 & \begin{tabular}{|l}
87.7 \\
\end{tabular} & 537 & 122 & 15.1 & 685 & 84.9 & 807 \\
\hline
\end{tabular}

Source: Authors' own 


\begin{tabular}{|c|c|c|c|c|c|c|c|c|c|c|}
\hline o & 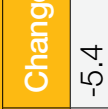 & : & 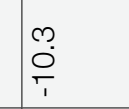 & $\dot{p}$ & $\frac{1}{\pi}$ & ָָ & $\begin{array}{ll}\infty \\
\dot{T} \\
\dot{T}\end{array}$ & is & & 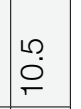 \\
\hline$\frac{\frac{0}{\frac{10}{2}}}{\frac{2}{2}}$ & 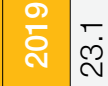 & 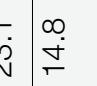 & $\begin{array}{l}\infty \\
\infty \\
\stackrel{\rho}{\infty}\end{array}$ & $\underset{\infty}{\infty}$ & ָָن & $\mid \begin{array}{l}0 \\
0 \\
0 \\
0\end{array}$ & \begin{tabular}{l|l}
$\infty$ \\
$\infty$ \\
$\infty$ \\
$\infty$
\end{tabular} & 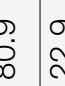 & & 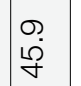 \\
\hline & 家 & $\begin{array}{l}\stackrel{\infty}{\circ} \\
\stackrel{\leftrightarrow}{\infty}\end{array}$ & $\overline{\stackrel{i}{i}}$ & $\wedge$ & $\begin{array}{l}0 \\
\vdots \\
0 \\
0\end{array}$ & $\hat{\grave{k}}$ & \begin{tabular}{c|c}
$\infty$ & 0 \\
$\infty$ & 0 \\
$\infty$ & 0
\end{tabular} & $b \begin{array}{l}a \\
a \\
a\end{array}$ & $\begin{array}{l}\dot{b} \\
\dot{j} \\
\text { in }\end{array}$ & 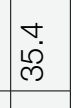 \\
\hline & تَ & 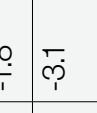 & 㒸 & $\mid \begin{array}{l}7 \\
6 \\
6 \\
9\end{array}$ & $\varphi$ & $\begin{array}{l}0 \\
\vdots \\
\end{array}$ & $\begin{array}{lll}0 & 0 \\
0 & 0 \\
0\end{array}$ & & : & స̃ \\
\hline 离 & 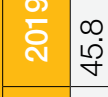 & 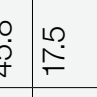 & 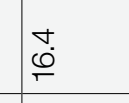 & $\infty_{\infty}^{\infty}$ & $\begin{array}{l}\infty \\
\vdots \\
0 \\
0\end{array}$ & $\tilde{a}$ & $\stackrel{\mathscr{c}}{\mathrm{s}} \hat{a}$ & $\stackrel{\infty}{\square}$ & $\underline{0}$ & $\stackrel{\infty}{\stackrel{\infty}{\check{~}}}$ \\
\hline & 啇 & : & m. & مِّ & 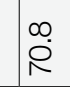 & 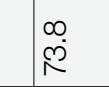 & 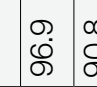 & 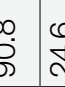 & 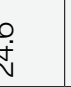 & के \\
\hline & 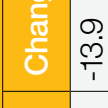 & 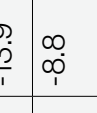 & $\bar{\varphi}$ & 0 & $\begin{array}{l}0 \\
\vdots \\
\vdots\end{array}$ & ণ & $\underset{\sim}{\infty}$ & 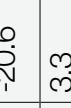 & $?$ & 六 \\
\hline$\frac{\bar{c}}{\bar{c}}$ & 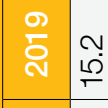 & $\stackrel{y}{2}$ & $\mathscr{\rho}$ & 0 & 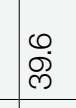 & $\begin{array}{l}\infty \\
\infty \\
\infty \\
\infty\end{array}$ & 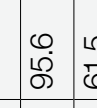 & \begin{tabular}{llll} 
\\
\hdashline
\end{tabular} & هُ & $\overline{\mathrm{N}}$ \\
\hline & 亏্ড & $\dot{\vec{j}}$ & $\stackrel{\circ}{\circ}$ & 0 & 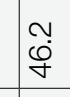 & 甪 & $\frac{m}{\dot{\alpha}} \dot{\alpha}$ & vid & vo & f \\
\hline & & \begin{tabular}{l|l} 
\\
$\vdots$ \\
$i$
\end{tabular} & $\frac{m}{p}$ & $\infty_{\infty}^{\infty}$ & רֶֶ & 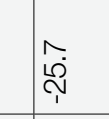 & 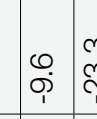 & : & Si & ָָ \\
\hline 㟧 & 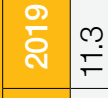 & 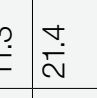 & 吕 & 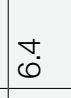 & 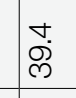 & in & $\begin{array}{lll}0 \\
0 \\
0\end{array}$ & 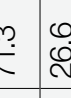 & : & ल) \\
\hline & 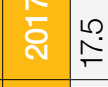 & 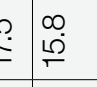 & $\begin{array}{l}\infty \\
\infty \\
\infty \\
\infty\end{array}$ & $\underset{j}{+}$ & $\stackrel{\mathscr{Q}}{\stackrel{0}{0}}$ & $\hat{\kappa}$ & $\stackrel{\circ}{\circ}$ & 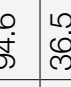 & 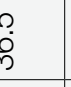 & 苟 \\
\hline & 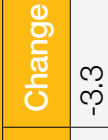 & & $\begin{array}{l}\tilde{\infty} \\
\propto \\
\phi\end{array}$ & $\widehat{\grave{\rho}}$ & $\pi$ & 䛿 & $\begin{array}{l}\infty \\
\substack{\infty \\
c} \\
\end{array}$ & 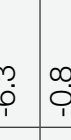 & : & مْ \\
\hline $\bar{b}$ & 商 $\frac{0}{m}$ & 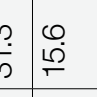 & 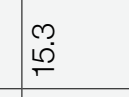 & $\underset{\substack{\infty \\
i \infty}}{10}$ & $\underset{\substack{\infty \\
\infty \\
\infty}}{\infty}$ & $\overline{\ddot{0}}$ & $\hat{a}$ & $\begin{array}{c}c \\
c \\
\infty \\
\infty\end{array}$ & ֶู & 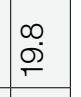 \\
\hline & \begin{tabular}{l|l}
$\hat{\bar{a}}$ \\
à \\
\end{tabular} & 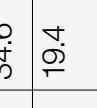 & 吕 & o & 苞 & \begin{tabular}{|l|} 
\\
\\
$\infty$ \\
$\infty$
\end{tabular} & 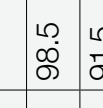 & & dָ. & 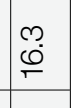 \\
\hline 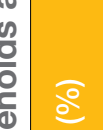 & $\mid$ & & $\hat{\stackrel{0}{T}}$ & $\begin{array}{l}N \\
\tilde{p}\end{array}$ & $\stackrel{\stackrel{N}{\rightleftharpoons}}{\bar{T}}$ & $\begin{array}{l}\infty \\
\substack{\infty \\
\frac{\infty}{1}}\end{array}$ & $\stackrel{+}{T}$ & 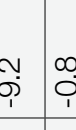 & : & | \\
\hline & 产 & 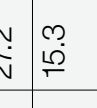 & 酋 & $\stackrel{\infty}{+}$ & 古 & 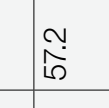 & $\hat{\phi}$ & $\begin{array}{c}\mathscr{D}_{\infty}^{\infty} \\
0\end{array}$ & הู & 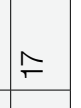 \\
\hline & হ̀ & 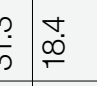 & $\begin{array}{l}\mathscr{\leftrightarrow} \\
\stackrel{\sim}{*}\end{array}$ & $\infty$ & 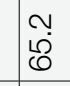 & 占 & $\bar{\infty}$ & ك. & & نْ \\
\hline & 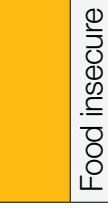 & 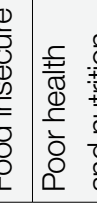 & 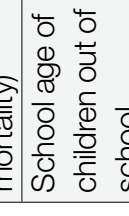 & & 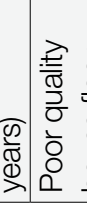 & 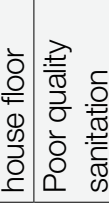 & 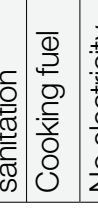 & 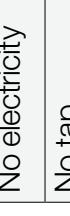 & 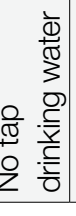 & 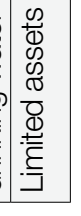 \\
\hline
\end{tabular}




\begin{tabular}{|c|c|c|c|c|c|c|c|c|}
\hline$\frac{}{\circ}$ & $\frac{0}{\frac{0}{2}} \frac{10}{0}$ & $\begin{array}{l}0 \\
\stackrel{0}{0} \\
1 \\
1\end{array}$ & $\frac{\bar{\sigma}}{\bar{T}}$ & $\begin{array}{l}\text { m. } \\
\stackrel{\top}{\sim}\end{array}$ & $\stackrel{\sim}{\sim}$ & $\begin{array}{l}\frac{2}{1} \\
\frac{1}{1}\end{array}$ & $\begin{array}{l}\underset{\infty}{\infty} \\
\infty \\
\frac{\infty}{1}\end{array}$ & \multirow{3}{*}{ 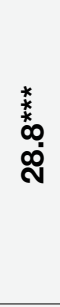 } \\
\hline \multirow{2}{*}{$\begin{array}{l}2 \\
\frac{2}{80} \\
0 \\
z\end{array}$} & $\frac{0}{2}$ & হু & $\mathbb{N}$ & Б) & $\begin{array}{l}\mathscr{\sigma} \\
\stackrel{f}{+}\end{array}$ & $\underset{\stackrel{N}{\sim}}{\stackrel{N}{*}}$ & $\begin{array}{l}L \\
\iota 0 \\
\llcorner \\
\end{array}$ & \\
\hline & 옹 & $\begin{array}{l}\bullet \\
\varnothing \\
\infty\end{array}$ & $\bar{\sigma}$ & $\begin{array}{l}\forall \\
\varnothing \\
\infty\end{array}$ & ه & $\frac{\hat{\sigma}}{\bar{\varphi}}$ & $\stackrel{N}{N}$ & \\
\hline$\frac{8}{4}$ & \begin{tabular}{|l}
$\frac{0}{0}$ \\
$\frac{2}{0}$ \\
$\frac{1}{0}$ \\
\end{tabular} & $\frac{\overline{0}}{\overline{1}}$ & 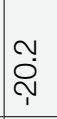 & $\stackrel{\vec{F}}{\bar{T}}$ & $\begin{array}{l}0 \\
0 \\
\frac{1}{1}\end{array}$ & 垈 & $\stackrel{\varphi}{\underset{T}{F}}$ & \multirow{3}{*}{ 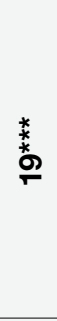 } \\
\hline$\frac{3}{2}$ & $\frac{0}{2}$ & $\begin{array}{l}\stackrel{\infty}{+} \\
\stackrel{+}{+}\end{array}$ & N & $\begin{array}{l}m \\
0 \\
0 \\
-\end{array}$ & $\stackrel{\llcorner}{\longrightarrow}$ & 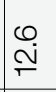 & $\begin{array}{l}0 \\
\stackrel{0}{1} \\
\stackrel{1}{L}\end{array}$ & \\
\hline z & 홍 & 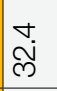 & $\underset{\stackrel{N}{\mathcal{V}}}{ }$ & $\stackrel{\infty}{\sim}$ & $\frac{m}{\bar{m}}$ & $\begin{array}{l}\stackrel{M}{\rho} \\
\stackrel{\rho}{\sim}\end{array}$ & 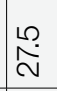 & \\
\hline \multirow{3}{*}{ 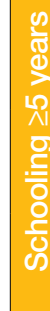 } & $\frac{\frac{0}{2}}{\frac{0}{0}}$ & $\underset{+}{\check{T}}$ & $\varphi$ & $\begin{array}{l}\infty \\
\text { î } \\
\end{array}$ & $P$ & $\frac{\infty}{\bar{T}}$ & 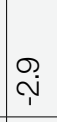 & \multirow{3}{*}{ 灾 } \\
\hline & के & $\curvearrowright$ & ${ }^{\circ}$ & $\hat{m}$ & 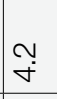 & $\hat{\circ}$ & $\nabla$ & \\
\hline & 훙 & $\stackrel{\infty}{\risingdotseq}$ & F & $\begin{array}{l}10 \\
0 \\
0\end{array}$ & $\stackrel{N}{N}$ & 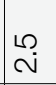 & $\begin{array}{l}0 \\
0 \\
0\end{array}$ & \\
\hline \multirow{3}{*}{$\begin{array}{l}\overline{8} \\
\frac{0}{0} \\
\text { D } \\
0 \\
\overline{3} \\
0 \\
\frac{0}{0} \\
\frac{0}{0}\end{array}$} & 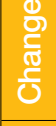 & $\underset{\frac{\infty}{1}}{\bar{\alpha}}$ & \begin{tabular}{l}
\multirow{1}{*}{} \\
$\stackrel{\sim}{1}$
\end{tabular} & $\begin{array}{l}\hat{\tilde{T}} \\
\bar{\Gamma}\end{array}$ & $\begin{array}{l}0 \\
0 \\
1 \\
\end{array}$ & 垈 & $\frac{0}{\Gamma_{1}}$ & \multirow{3}{*}{ 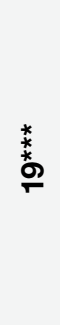 } \\
\hline & $\frac{\pi}{2}$ & $\begin{array}{l}\mathscr{O} \\
\stackrel{\sim}{\leftarrow}\end{array}$ & N & $\begin{array}{l}\infty \\
\stackrel{\infty}{0} \\
\stackrel{0}{*}\end{array}$ & $\stackrel{10}{\longrightarrow}$ & $\begin{array}{l}\stackrel{\leftrightarrow}{\mathrm{i}} \\
\stackrel{\sim}{\circ}\end{array}$ & 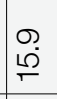 & \\
\hline & 훙 & 尺ें & $\underset{\stackrel{N}{\sim}}{\stackrel{N}{*}}$ & $\stackrel{\infty}{\sim}$ & $\frac{m}{ल}$ & $\begin{array}{l}\stackrel{M}{\rho} \\
\stackrel{\rho}{\Gamma}\end{array}$ & $\begin{array}{l}\stackrel{1}{2} \\
\stackrel{N}{~}\end{array}$ & \\
\hline \multirow{3}{*}{$\begin{array}{l}\frac{3}{7} \\
\frac{7}{\frac{T}{2}} \\
\frac{0}{0} \\
\frac{0}{0} \\
\frac{0}{0}\end{array}$} & $\frac{0}{\frac{8}{8}}$ & 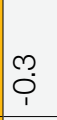 & ఠं & $\begin{array}{l}10 \\
P \\
1\end{array}$ & $\uparrow$ & $\stackrel{N}{N}$ & P & \multirow{3}{*}{$\stackrel{*}{\stackrel{*}{\sigma}}$} \\
\hline & $\frac{1}{2}$ & $\stackrel{\wedge}{\sigma}$ & 舍 & $\begin{array}{l}\stackrel{L}{+} \\
\underset{T}{+}\end{array}$ & 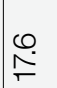 & 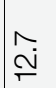 & $\begin{array}{l}\stackrel{\sim}{\omega} \\
\stackrel{\rho}{\tau}\end{array}$ & \\
\hline & 훙 & 尺 & 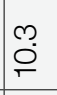 & $\stackrel{\infty}{-}$ & $\begin{array}{l}0 \\
\stackrel{\sim}{N}\end{array}$ & \begin{tabular}{l}
10 \\
0 \\
\hdashline
\end{tabular} & $\begin{array}{l}\infty \\
\infty \\
\infty\end{array}$ & \\
\hline \multirow{3}{*}{ 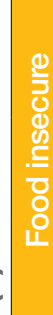 } & है & 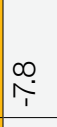 & $\wedge$ & $\begin{array}{l}\infty \\
\infty \\
\frac{\infty}{1}\end{array}$ & $\begin{array}{l}\text { No } \\
\text { ọ }\end{array}$ & P & P & \multirow{3}{*}{\begin{tabular}{l} 
* \\
\multirow{2}{*}{} \\
ลें
\end{tabular}} \\
\hline & i) & 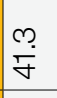 & $\begin{array}{l}\text { O } \\
\text { f }\end{array}$ & $\stackrel{\vec{N}}{\bar{N}}$ & 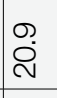 & @̊ & $\begin{array}{l}\stackrel{N}{\omega} \\
\stackrel{\rho}{\Gamma}\end{array}$ & \\
\hline & $\frac{1}{2}$ & চ্gি & 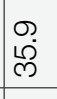 & $\begin{array}{l}\text { ले } \\
\text { ळ) }\end{array}$ & $\underset{\check{N}}{\bar{N}}$ & $\stackrel{\infty}{\sim}$ & $\begin{array}{l}\tilde{N} \\
\infty \\
\propto\end{array}$ & \\
\hline & $\overline{0}$ & $\begin{array}{l}\stackrel{1}{\uparrow} \\
\vdots \\
0\end{array}$ & $\begin{array}{l}9 \\
\frac{1}{N} \\
\end{array}$ & $\begin{array}{l}8 \\
\frac{1}{\gamma} \\
\frac{1}{4}\end{array}$ & $\begin{array}{l}\infty \\
1 \\
\frac{1}{6}\end{array}$ & $\frac{8}{\frac{1}{\infty}}$ & 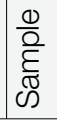 & 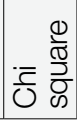 \\
\hline
\end{tabular}


Annex 3 (b) Source of livelihood by commercialisation index

\begin{tabular}{|c|c|c|c|c|c|c|c|c|c|c|c|c|}
\hline Deprived & \multicolumn{3}{|c|}{ Cooking fuel } & \multicolumn{3}{|c|}{ Electricity } & \multicolumn{3}{|c|}{ Drinking water } & \multicolumn{3}{|c|}{ Assets } \\
\hline $\mathrm{RCl}$ & 2017 & 2019 & Change & 2017 & 2019 & Change & 2017 & 2019 & Change & 2017 & 2019 & Change \\
\hline $0-20$ & 100 & 74.5 & -25.5 & 98.5 & 89 & -9.5 & 28.4 & 35.2 & 6.8 & 16.4 & -16.4 & -32.8 \\
\hline $21-40$ & 100 & 100 & 0 & 91.1 & 84.7 & -6.4 & 26.7 & 24.6 & -2.1 & 13.3 & 17.8 & 4.5 \\
\hline $41-60$ & 96.3 & 96.7 & 0.4 & 96.3 & 80.5 & -15.8 & 22.4 & 20.9 & -1.5 & 13.1 & 14.4 & 1.3 \\
\hline $61-80$ & 98.8 & 97.2 & -1.6 & 90.4 & 83.6 & -6.8 & 27.1 & 17.3 & -9.8 & 10.2 & 14 & 3.8 \\
\hline $81-100$ & 98 & 94.2 & -3.8 & 79.2 & 67.4 & -11.8 & 15.8 & 18.5 & 2.7 & 5 & 9.6 & 4.6 \\
\hline Sample & 94.5 & 96.1 & 1.6 & 90.1 & 80.7 & -9.4 & 90.1 & 80.7 & -9.4 & 10.7 & 15 & 4.3 \\
\hline Chi square & \multicolumn{3}{|c|}{5.01} & \multicolumn{3}{|c|}{$26^{\star \star *}$} & \multicolumn{3}{|c|}{6.3} & \multicolumn{3}{|c|}{7.4} \\
\hline
\end{tabular}

Source: Authors' own 


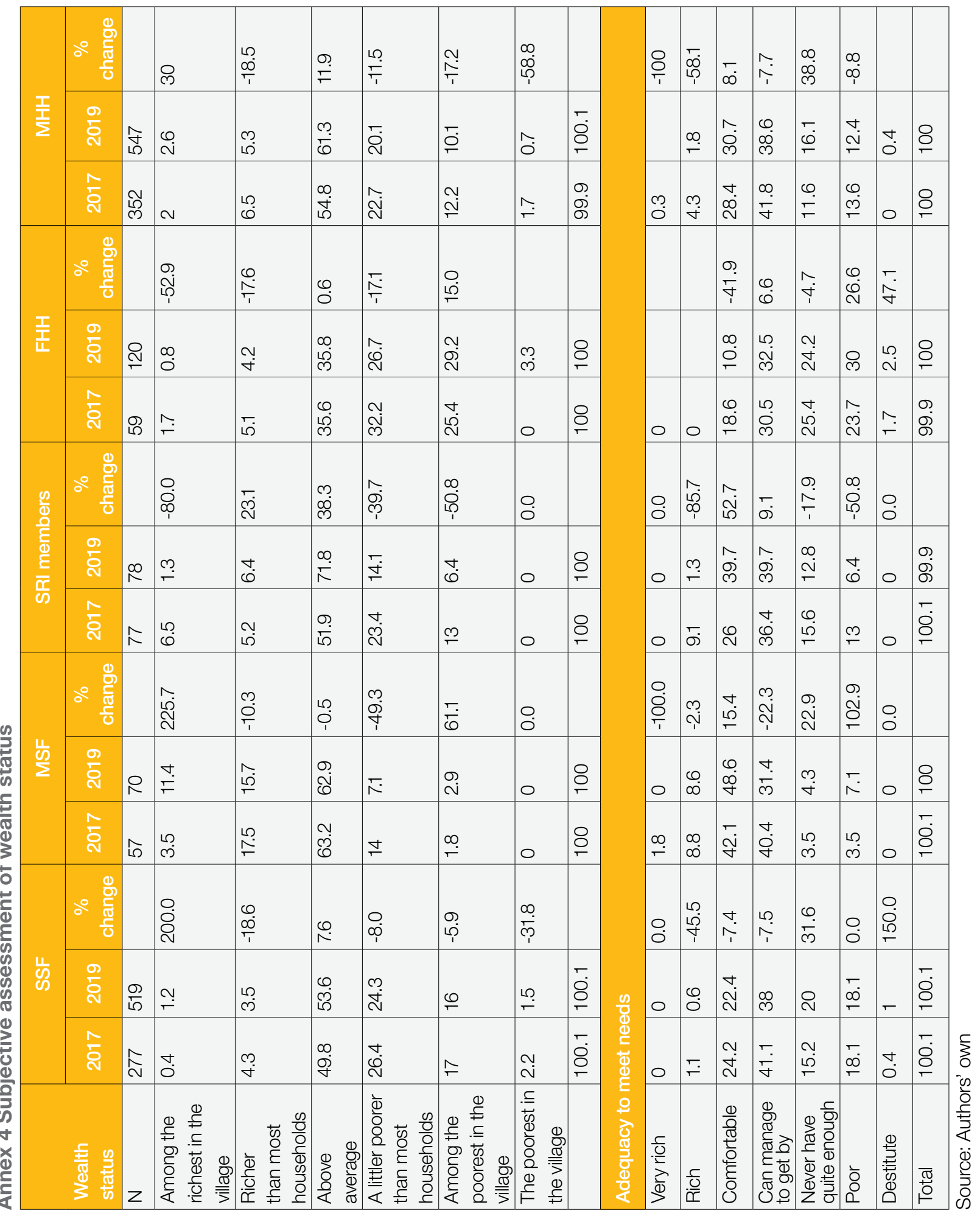


Isinika, A., Mlay, G., Mdoe, N., Boniface, G., Magomba, C. and Kilave, D. (2021) Rice Commercialisation Effects in Mngeta, Kilombero District, Tanzania: Identifying the Underlying Factors, APRA Working Paper 63, Brighton: Future Agricultures Consortium

(c) APRA 2021

ISBN: 978-1-78118-846-0

DOI: 10.19088/APRA.2021.022

\section{(cC) BY-NC-ND}

This is an Open Access report distributed under the terms of the Attribution-Non Commercial-No Derivs 4.0 Unported (CC BY-NC-ND 4.0) Attribution - You must give appropriate credit, provide a link to the license, and indicate if changes were made. You may do so in any reasonable manner, but not in any way that suggests the licensor endorses you or your use. NonCommercial — You may not use the material for commercial purposes. NoDerivatives - If you remix, transform, or build upon the material, you may not distribute the modified material. You are free to: Share - copy and redistribute the material in any medium or format.

https://creativecommons.org/licenses/by-nc-nd/4.0/legalcode

If you use the work, we ask that you reference the APRA website (www.future-agricultures.org/apra/) and send a copy of the work or a link to its use online to the following address for our archive: APRA, Future Agricultures Consortium, University of Sussex, Brighton BN1 9RE, UK (apra@ids.ac.uk)

All APRA Working Papers go through a review process before publication.

\section{@creative}

\section{DO YOU HAVE COMMENTS ON THIS PAPER?}

We would welcome your feedback on this working paper!

To provide brief comments, please follow this link to our short APRA Working Paper Feedback form: https://goo.gl/forms/1iVnXhhrIGesfR9

Agricultural Policy Research in Africa (APRA) is a programme of the Future Agricultures Consortium (FAC) which is

generating new evidence and policy-relevant insights on more inclusive pathways to agricultural commercialisation in sub-Saharan Africa. APRA is funded with UK aid from the UK Foreign, Commonwealth \&

Development Office (FCDO) and will run from 2016-2022.

The APRA Directorate is based at the Institute of Development Studies (IDS), UK (www.ids.ac.uk), with regional hubs at the Centre for African Bio-Entrepreneurship (CABE), Kenya, the Institute for Poverty, Land and Agrarian Studies (PLAAS), South Africa, and the University of Ghana, Legon. It builds on more than a decade of research and policy engagement work by the Future Agricultures Consortium (www.future-agricultures.org) and involves more than 100 researchers and communications professionals in Africa, UK, Sweden and USA. 